\title{
Amino Acid-Based Synthesis and Glycosidase Inhibition of Cyclopropane-Containing Iminosugars
}

\author{
Alejandro Puet, Gema Domínguez, F. Javier Cañada, and Javier Pérez-Castells*
}

Cite This: ACS Omega 2020, 5, 31821-31830

Read Online

ABSTRACT: Synthesis of four iminosugars fused to a cyclopropane ring is described using L-serine as the chiral pool. The key steps are large-scale preparation of an $\alpha, \beta$-unsaturated piperidinone followed by completely stereoselective sulfur ylide cyclopropanation. Stereochemistry of compounds has been studied by nuclear Overhauser effect spectroscopy (NOESY) experiments and ${ }^{1} \mathrm{H}$ homonuclear decoupling to measure constant couplings. The activity of these compounds against different glycosidases has been evaluated. Although inhibition activity was low (compound 8a presents a $\left(K_{\mathrm{i}}\right)$ of $1.18 \mathrm{mM}$ against $\beta$ galactosidase from Escherichia coli), interestingly, we found that

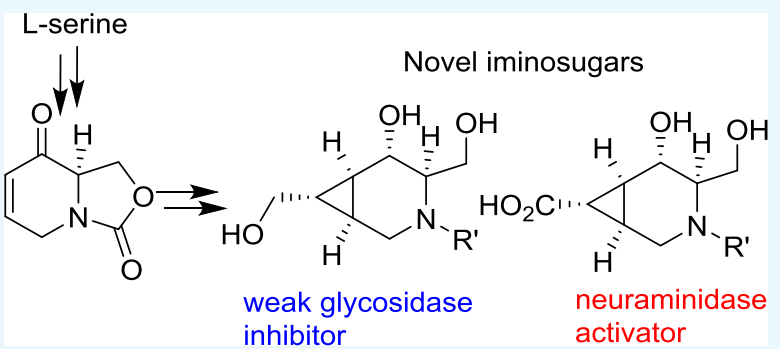
compounds $\mathbf{8 a}$ and $\mathbf{8 b}$ increase the activity of neuraminidase from Vibrio cholerae up to $100 \%$.

\section{INTRODUCTION}

Iminosugars are azaheterocycles with promising biological activities such as glycosidase and glycosyltransferase inhibition and modulation. ${ }^{1}$ Many iminosugars are natural or synthetic polyhydroxylated piperidines, which can act as biomimetics of their corresponding pyranose analogues. Some of the most important natural piperidine iminosugars are nojirimycin (Figure 1, I) and its epimers, which, together with their deoxy analogues have turned out to be the lead molecules for drug design. Thus, stereochemical changes and functional group variation have led to iminosugars that can modulate glycosidase enzymes, exhibiting immunosuppressive, antiviral, or anti-inflammatory activities. ${ }^{2}$ Bicyclic iminosugars, such as swainsonine (II), lentiginosine (III), castanospermine (IV), and their derivatives exhibit antitumor and immunosuppressive activities. $^{3}$

Several iminosugars, miglitol (Glyset, V), ${ }^{4}$ migalastat (Galafold, VI), ${ }^{5}$ and miglustat (Zavesca, VII) ${ }^{6}$ are commercially available for the treatment of type II diabetes and Fabry disease, and as the first oral treatment for Gaucher disease, respectively. Several other competitive inhibitors of glycosidases are being developed as new drugs and are in different phases of clinical trials.

The mechanism associated with glycosidase activity modulation is generally attributed to structural similarity to the oxacarbenium ion-like transition-state, formed during the hydrolysis of carbohydrates. ${ }^{7}$ These transition states present diverse conformational pathways for different glycosidases, ${ }^{8}$ making selective inhibition possible. In this context, designing conformationally restricted inhibitors seems to be an interesting approach. In addition, adequate metabolic stability is needed, which may be achieved with more rigid compounds. Recently, a study on $\alpha$-mannanases showed how the enzyme surface restricts the conformational landscape of the substrate, rendering the $B_{2,5}$ conformation the most stable on-enzyme (Figure 2a). ${ }^{9}$ In another study, a cyclopropane containing a cyclophellitol analogue, was designed as a specific $\beta$ glucosidase inhibitor for enzymes reacting through the ${ }^{4} \mathrm{H}_{3}$ transition-state conformation (Figure $2 \mathrm{~b}$ ). ${ }^{10}$

With these precedents, we expected that the introduction of a three-membered ring annulated to a piperidine ring would render novel iminosugars with a locked conformation that may be the starting point for finding the therapeutic compounds (Figure 3). The substituted cyclopropane moiety renders a fixed conformation and allows many different configurations that could increase selectivity to specific glycosidases.

The development of efficient routes for the preparation of iminosugars has received much attention from the synthetic community. ${ }^{11}$ Most of the methods use carbohydrates as the chiral pool, which are transformed using reductive aminations ${ }^{12}$ or other transformation strategies. ${ }^{13}$ Alternatively, some asymmetric or biocatalysed approaches have been used. ${ }^{14}$ But, there are fewer reports on approaches where amino acids are used as the chiral pool for the synthesis of iminosugar derivatives. $^{15}$

Herein, we envisioned the preparation of novel bicyclic iminosugars that include the cyclopropane motif fused with piperidine starting from the natural amino acid L-serine as the

Received: September 18, 2020

Accepted: October 29, 2020

Published: December 2, 2020 


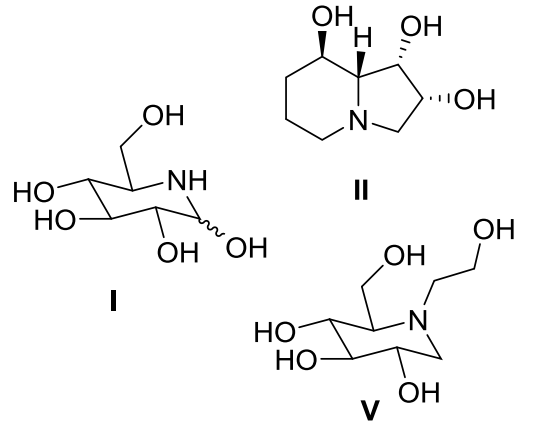

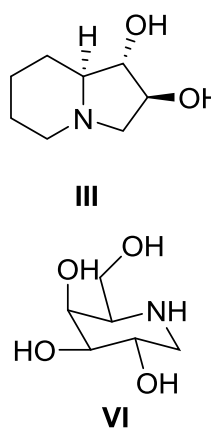

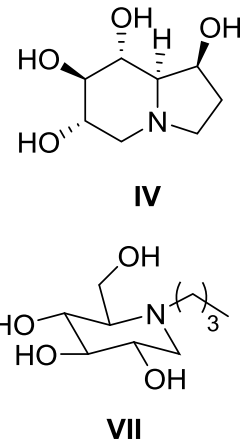

Figure 1. Structures of nojirimycin (I), swainsonine (II), lentiginosine (III), castanospermine (IV), miglitol (V), migalastat (VI), and miglustat (VII).

(a)

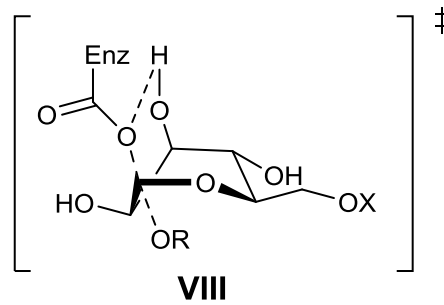

$B_{2,5}$ conformation (ref 9) (b)<smiles>[R]C1[C@H]2[C@@H](CO)[C@H](O)[C@H](O)[C@H](O)[C@H]12</smiles>

IX

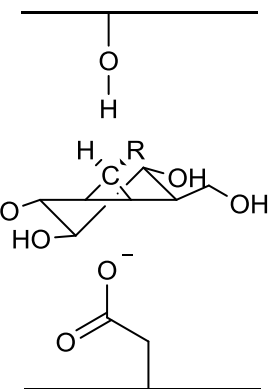

cyclophellitol analogue. The $\overline{{ }^{4} \mathrm{H}_{3} \text { conformation }}$

(ref 10)

Figure 2. Transition-state conformations on-enzyme: (a) mannose $B_{2,5}$ conformation (VIII, reprinted with permission from ref 9 ) and (b) cyclophellitol analogue and its ${ }^{4} \mathrm{H}_{3}$ conformation (IX, ref 10, copyright 2017 American Chemical Society).<smiles>[R]C1C2CNC(CO)C(O)C12</smiles>

Figure 3. Structure of the target compound.

chiral pool. The final compounds present five stereogenic centers, and the synthesis involves the inversion of the configuration of the starting L-serine ( $S$-configuration) into the C5 configuration of D-carbohydrates $(R) .{ }^{96}$ Preliminary glycosidase inhibition evaluation is shown.

\section{RESULTS AND DISCUSSION}

Our first goal was the synthesis of $\alpha, \beta$-unsaturated ketone 5 in which the chiral center has $R$ configuration. This configuration was selected as it corresponds to $\mathrm{C} 5$ in natural sugars and iminosugars, which share the $R$ configuration in that position. This compound has already been prepared from D-serine and described. ${ }^{17}$ In our case, we developed a synthesis approach using cheaper and natural L-serine, as depicted in Scheme 1. From this intermediate, a cyclopropanation reaction and further transformations resulted in a new family of piperidines fused to cyclopropanes. L-Serine was esterified and protected with $\mathrm{Boc}_{2} \mathrm{O}$, and the resulting intermediate was further protected and reduced to give desymmetrized alcohol $\mathbf{1}$ in which the configuration has changed from $S$ to $R$ in a few steps. This compound $\mathbf{1}$ was transformed into oxazolidinone by reaction with a base followed by allylation to give compound 2 . Following the previously reported methodology, ${ }^{18} \mathbf{2}$ was deprotected and oxidized into carboxylic acid 3. This was
Scheme 1. Synthesis of Compound 5
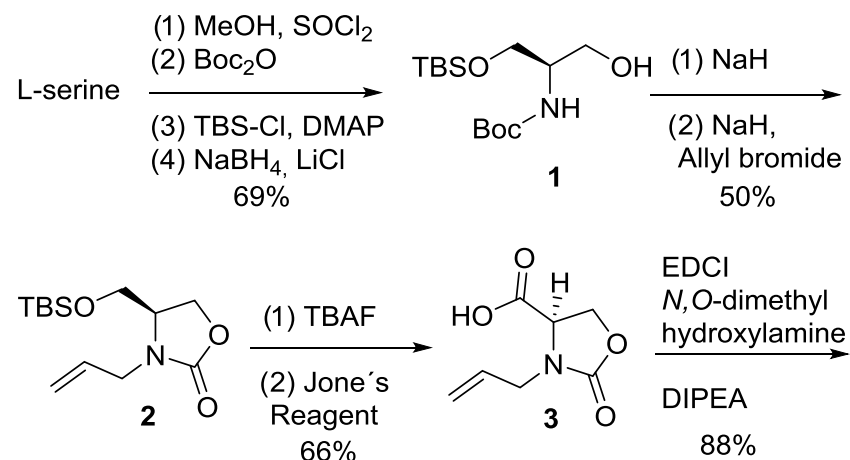<smiles>C=CCN1C(=O)OC[C@H]1C(=O)N(C)OC</smiles><smiles>O=S(=O)(O)/C=C\C=C/Br</smiles><smiles>O=C1C=CCN2C(=O)OC[C@H]12</smiles>

converted into Weinreb amide 4, which was treated with vinylmagnesium bromide and subjected to a ring-closing metathesis, RCM, using second-generation Grubbs' catalyst (Grubbs Catalyst M204), giving the starting material 5. ${ }^{19}$ This precursor containing the piperidine core was obtained in $13 \%$ global yield after 11 steps. No racemization was observed during the synthesis.

The cyclopropanation reaction of $\mathbf{5}$ was performed using sulfur ylide. Interestingly, only one reaction product was observed and isolated in $70 \%$ yield. This product was designated as structure 6, as a result of NMR analysis (nuclear 
Overhauser effect (NOE) and coupling constants) of compounds $7 \mathbf{a}-\mathbf{b}$ (vide infra). Cyclopropanation occurred on the same side of oxazolidinone (endo attack) and the subsequent ring-closing step exclusively gave exo-cyclopropane. The ylide mediated cyclopropanation is a stepwise reaction in which the formation of the first $\mathrm{C}-\mathrm{C}$ bond is the ratedetermining step. $^{20}$ The attack of the ylide on $\mathbf{5}$ is more favored from the opposite face to the nitrogen lone electron pair as depicted in Scheme2; therefore, it occurs through the

Scheme 2. Stereoselectivity of the Cyclopropanation Reaction of $5^{24}$

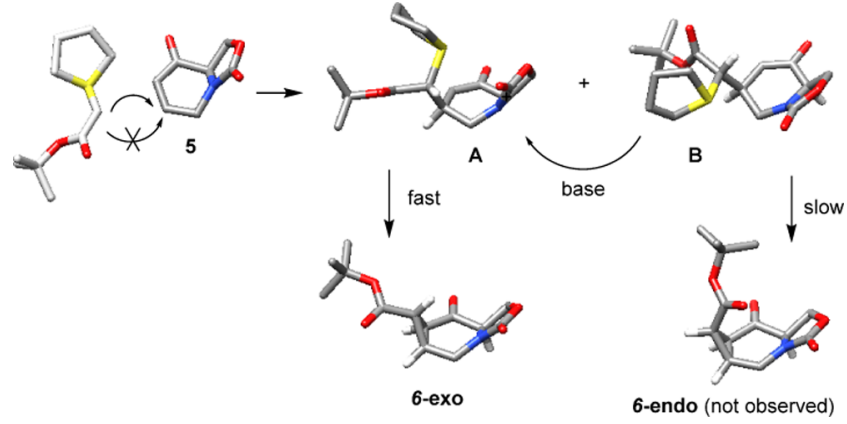

same face of the oxazolidinone ring (endo). This selectivity was observed previously in one unsaturated $\gamma$-lactam cyclopropanation, ${ }^{21}$ although other precedents have described mixtures of endo and exo attacks. ${ }^{22}$ Then, the stereoselectivity of cyclopropane is determined in the second step. Studies reported by Aggarwal's group, ${ }^{23}$ showed that two intermediate betaines $\mathbf{A}$ and $\mathbf{B}$ are formed in a 1:1 ratio after the nucleophilic addition. The cyclization of betaine $\mathbf{A}$ is faster than that of B. Moreover, $\mathbf{B}$ can epimerize to give $\mathbf{A}$ before it closes the three-membered ring generally leading to high diastereoselectivity of exo-cyclopropane.
With the cyclopropane containing compound $\mathbf{6}$ in hand, the reduction of the ketone afforded a (3:2) mixture of the two diastereomers $7 \mathbf{a}-\mathbf{b}$ (Scheme 3). These alcohols were separated, characterized, and separately transformed into the final products. The stereochemistry of $7 \mathbf{a}$ and $7 \mathbf{b}$ was determined using NOE experiments and coupling constant values. Figure 4 shows the main correlations observed for $7 \mathbf{a}$
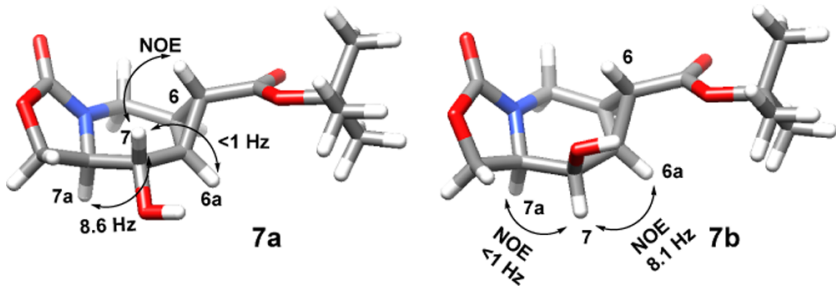

Figure 4. NOE signals and constant couplings in products $7 \mathbf{a}$ and $7 \mathbf{b}$, respectively. $^{24}$

and $\mathbf{7 b}$ that allowed assigning the relative configuration of $\mathrm{H} 6$, $\mathrm{H} 7$, and H7a. The coupling constants between $\mathrm{H} 7 \mathrm{a}, \mathrm{H} 7$, and H6a were determined using homonuclear decoupling experiments. Values are shown in Figure 4, and the model agrees with the calculated angles for these couplings.

In continuation of the synthesis, treatment with trifluoroacetyl (TFA) and further reaction with ethylendiamine gave products $\mathbf{8 a}$ and $\mathbf{8 b}$, respectively, in excellent yields. On the other hand, compounds $7 \mathbf{a}$ and $7 \mathbf{b}$ gave different products on reacting with DIBAL- $\mathrm{H}$, whereas $7 \mathbf{b}$ gave the expected alcohol $10(62 \%)$, additionally, the reaction of $7 \mathrm{a}$ caused the cleavage of the oxazolidinone ring giving 9 in $58 \%$ yield. This behavior has been described previously (Scheme 3 ). ${ }^{25}$

Final compounds were screened for glycosidase inhibition activities ( $\alpha$-glucosidase from Bacillus stearothermophilus, $\beta$ glucosidase from almonds, $\alpha$-galactosidase from green coffee beans, $\beta$-galactosidase from Escherichia coli, $\alpha$-mannosidase

\section{Scheme 3. Synthesis of Final Compounds from 5}

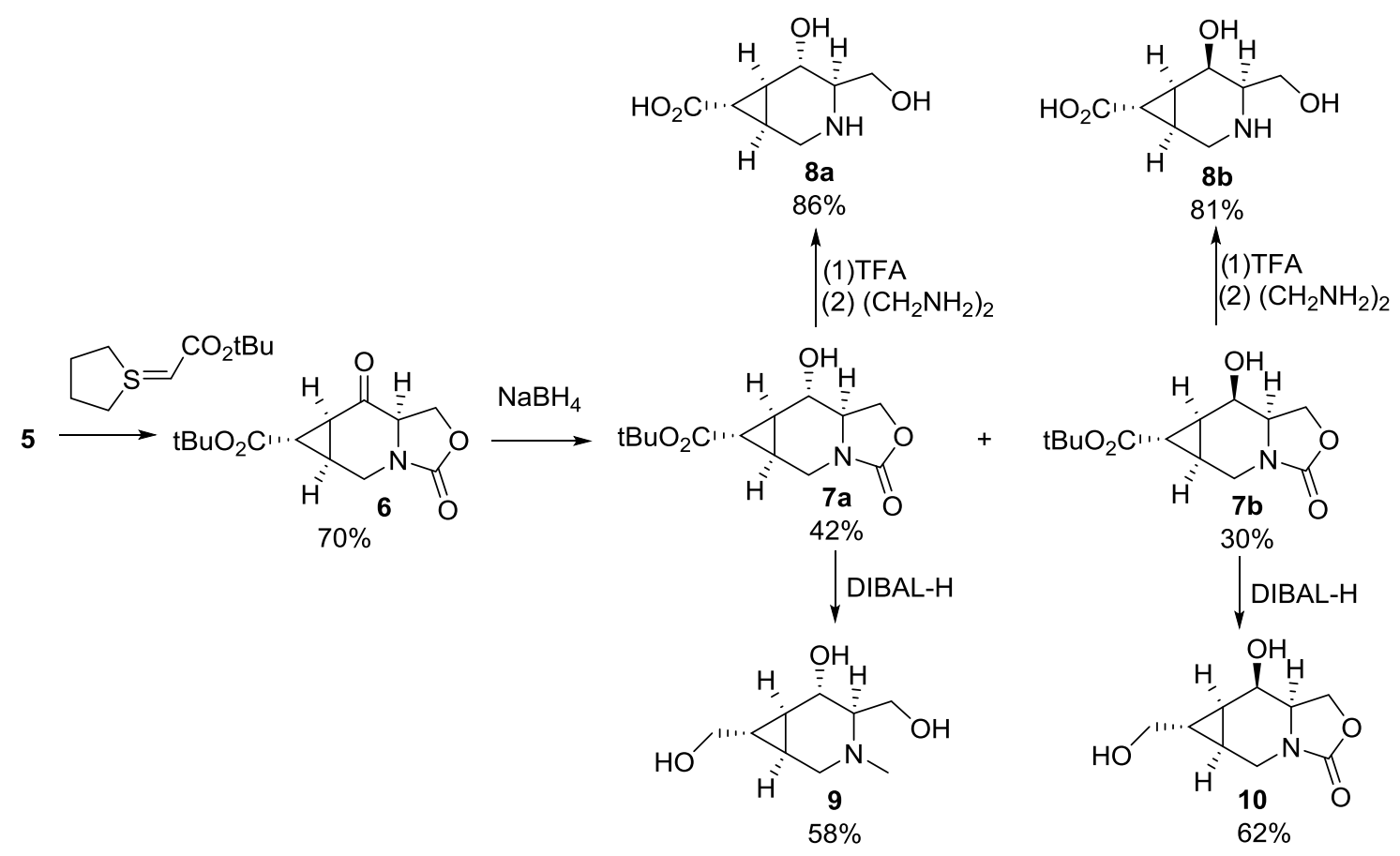


from Jack beans, $\beta$-mannosidase from Helix pomatia, and $\alpha$-Lfucosidase from Homo sapiens) using $p$-nitrophenyl monosaccharides as substrates.

Carboxylic containing compounds $\mathbf{8 a}$ and $\mathbf{8 b}$, could resemble the zwitterionic form of oseltamivir and zanamivir, well-known inhibitors of neuraminidase from Influenza virus ${ }^{26}$ with carboxyl-amino and carboxyl-guanidine moieties, respectively. Preliminary docking calculations using AutoDock ${ }^{27}$ showed that $\mathbf{8 a}$ and $\mathbf{8 b}$ could fit in the binding site of neuraminidase. Thus they were also evaluated as possible inhibitors of neuraminidase from Vibrio cholerae.

The enzymatic activities were calculated by measuring the absorbance of the phenoxide released in the enzymatic reaction at $405 \mathrm{~nm}$. The compounds were initially screened at 1,5 , and $25 \mathrm{mM}$ concentrations. With compounds $\mathbf{8 a}$ and $\mathbf{9}$, inhibition over $50 \%$ was observed with selected enzymes at $5 \mathrm{mM} ; 8 \mathrm{~b}$ and $\mathbf{1 0}$ did not show any significant inhibition of any glycosidase (Chart 1$)$. Inhibition constants $\left(K_{\mathrm{i}}\right)$ were

Chart 1. Residual Glycosidase Activities in the Presence of 5 mM Synthesized Compounds

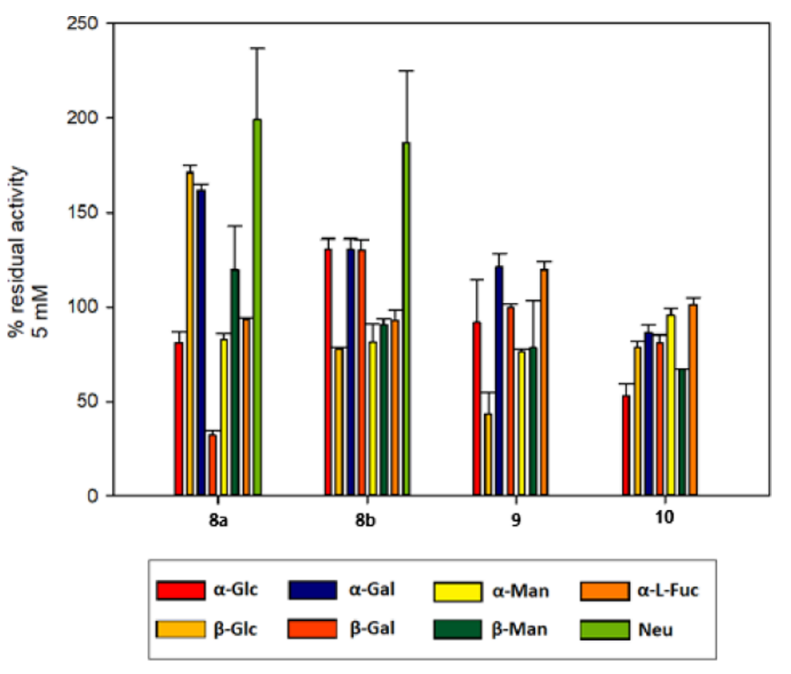

estimated assuming a competitive type inhibition in the cases of compound 8a against $\beta$-galactosidase $\left(K_{\mathrm{i}}=1.18 \mathrm{mM}\right)$ and 9 against $\beta$-glucosidase $\left(K_{\mathrm{i}}=4.43 \mathrm{mM}\right)$. These two compounds exhibit some selectivity such that even at $25 \mathrm{mM}$ no significant inhibition was observed against other glycosidases.

However, the observed inhibition was very weak compared to other iminosugar-based glycosidase inhibition, for example the measured $K_{\mathrm{i}}$ for deoxinojirimycin (DNJ) is $0.44 \mu \mathrm{M}$ for $\alpha$ glucosidase from $B$. stearothermophilus. The inhibition constant changes depending on the species that is studied, even for the same glycosidase of other species. ${ }^{28}$ Other iminosugars present great activity against mannosidases. ${ }^{29}$

On the other hand, we found that compounds $\mathbf{8 a}$ and $\mathbf{8 b}$, bearing a carboxylate group, also did not show any inhibition against neuraminidase but unexpectedly produced activation of the enzyme; these two compounds increased neuraminidase activity up to $100 \%$. The possibility that the compounds act as favorable transglycosylation acceptors causing an increase of nitrophenol release was considered. NMR experiments were performed continuously following the reaction, but potential transient transglycosylation products could not be observed. Further research to explain this behavior is needed. Interestingly there are not many precedents on glycosidase activation by iminosugars. Two reports have accounted for this activation behavior. Thus, up to 70-fold activation of some of glycosidases was detected with multivalent iminosugars. ${ }^{30}$ In another study, thienopyrimidines were found to activate certain glycosidases. ${ }^{31}$ The activation mechanism could be explained by the stabilization of the active structure of the enzyme by the introduction of a small molecule adjacent/close to the substrate-binding site, locking the reactive form. Alternatively, if the activation is of the allosteric type occurring in a site different from the active site, it could be interesting to check if the activators have any pharmacological chaperone activity but avoid the temporal inhibition of the enzymatic activity, unlike the aforementioned migalastat and other proposed pharmacological chaperones that help maintaining the correct fold of the protein although temporally blocking the active site of the enzyme.

\section{CONCLUSIONS}

We described a multigram synthesis of an $\alpha, \beta$-unsaturated ketone, which upon a stereoselective cyclopropanation reaction and further transformations gave a novel series of bicyclic piperidine-based iminosugars. The final products were studied against different glycosidases. Inhibition in most cases was low, but interestingly, the activation of neuraminidase was observed with products 8. Possible explanations of this behavior, for example, allosteric activation, enzyme stabilization, or transglycosylation acceptor activity can be proposed. Current studies in our lab will provide insight into these possible mechanisms, and their potential applications will be explored/ pursued.

\section{EXPERIMENTAL SECTION}

General Information. All chemicals were obtained from Aldrich/Merck, VWR, Fluorochem, and ABCR. Thin-layer chromatography (TLC) analyses were performed on Merck silica gel 60 F254 plates using phosphomolybdic acid or anisaldehyde and heat for detection. Silica gel NORMASIL 60 $40-63 \mu \mathrm{m}$ was used for flash chromatography. NMR spectra were recorded on a Bruker spectrometer $\left(400 \mathrm{MHz}\right.$ for ${ }^{1} \mathrm{H}$ and $100 \mathrm{MHz}$ for $\left.{ }^{13} \mathrm{C}\right)$. Chemical shifts are reported in $\delta \mathrm{ppm}$ referenced to $\mathrm{CDCl}_{3}\left(\delta=7.26\right.$ for ${ }^{1} \mathrm{H}$ and 77.00 for $\left.{ }^{13} \mathrm{C}\right)$, $\mathrm{CD}_{3} \mathrm{OD}\left(\delta=3.31\right.$ for ${ }^{1} \mathrm{H}$ and 49.00 for $\left.{ }^{13} \mathrm{C}\right)$, or $\mathrm{D}_{2} \mathrm{O}(\delta=4.79$ for ${ }^{1} \mathrm{H}$ ). Bidimensional spectra (heteronuclear multiple quantum coherence (HMQC), heteronuclear multiple bond coherence (HMBC), correlated spectroscopy (COSY), and nuclear Overhauser effect spectroscopy (NOESY)) were recorded in order to carry out the assignment. IR spectra were recorded on a Perkin-Elmer Spectrum 100. Specific optical rotation was measured using a polarimeter Anton Parr MCP 100. Melting points of solid compounds were determined using a Stuart Scientific Melting Point Apparatus SMP3. The absorbance of $p$-nitrophenoxide released in the enzymatic reactions was measured at $405 \mathrm{~nm}$ in a Perkin-Elmer Lamba 25.

Methyl (tert-Butoxycarbonyl)-L-serinate. Thionyl chloride $(83 \mathrm{~mL}, 1.1 \mathrm{~mol})$ was added to methanol $(280 \mathrm{~mL})$ at $0{ }^{\circ} \mathrm{C}$, then L-serine $(60.00 \mathrm{~g}, 571 \mathrm{mmol})$ is added. After $10 \mathrm{~min}$, at 0 ${ }^{\circ} \mathrm{C}$, the solution is heated at $65{ }^{\circ} \mathrm{C}$ for $2 \mathrm{~h}$. The solvent is evaporated in vacuo, and $600 \mathrm{~mL}$ of AcOEt and a saturated solution of $\mathrm{NaHCO}_{3}$ (until basic $\mathrm{pH}$ ) are added. Di-tert-butyl dicarbonate $(124.62 \mathrm{~g}, 0.571 \mathrm{mmol})$ in $265 \mathrm{~mL}$ of AcOEt is added. The reaction is stirred overnight at room temperature. 
The aqueous layer is extracted with AcOEt $(2 \times 300 \mathrm{~mL})$. The combined organic layers are washed with brine $(200 \mathrm{~mL})$, dried over $\mathrm{MgSO}_{4}$, and evaporated in vacuo. The crude product is filtered through a pad of silica gel using Hex/AcOEt (9:1) to $\mathrm{Hex} / \mathrm{AcOEt}$ (3:1) as eluents. A colorless oil is obtained (101.6 g, $81 \%$ after two steps). ${ }^{1} \mathrm{H}$ NMR $\left(400 \mathrm{MHz}, \mathrm{CDCl}_{3}\right) \delta 5.46$ (brs, $1 \mathrm{H}, \mathrm{NH}), 4.39$ (brs, $1 \mathrm{H}, \mathrm{CH}), 3.99-3.89(\mathrm{~m}, 2 \mathrm{H}$, $\mathrm{CH}_{2} \mathrm{O}$ ), 3.78 (s, 3H, OMe), 2.47-2.32 (m, 1H, OH), 1.45 (s, $\left.9 \mathrm{H}, 3 \times \mathrm{CH}_{3}\right) \cdot{ }^{13} \mathrm{C} \mathrm{NMR}\left(100 \mathrm{MHz}, \mathrm{CDCl}_{3}\right) \delta 171.6,155.9$, 80.3, 63.3, 55.8, 52.8, 28.3 (3C). IR ( NaCl): 3378, 2984, 2868, $1740,1708 \mathrm{~cm}^{-1}$. $[\alpha]_{\mathrm{D}}{ }^{25}$ (c 0.13 in dichloromethane (DCM)): +4.14. Found: C, 49.1; $\mathrm{H}, 7.9 \%$. Calc. for $\mathrm{C}_{9} \mathrm{H}_{17} \mathrm{NO}_{5}$ : C, 49.3; H, 7.8\%.

tert-Butyl (R)-(1-((tert-Butyldimethylsilyl)oxy)-3-hydroxypropan-2-yl)carbamate (1). To a solution of methyl (tertbutoxycarbonyl)-L-serinate $(101.4 \mathrm{~g}, 463 \mathrm{mmol})$ in $400 \mathrm{~mL}$ of dimethylformamide (DMF) cooled to $0{ }^{\circ} \mathrm{C}$ is added imidazole (37.8 g, $555 \mathrm{mmol}$ ) and 4-dimethylaminopyridine (DMAP; 5.6 g, $46 \mathrm{mmol}$ ). After $10 \mathrm{~min}$, tert-butyldimethylsilyl chloride $(73.2 \mathrm{~g}, 486 \mathrm{mmol})$ is added. The reaction is stirred for $30 \mathrm{~min}$ at room temperature. AcOEt $(400 \mathrm{~mL})$ is added, and the organic layer is washed with water $(3 \times 1 \mathrm{~L})$ and brine $(400$ $\mathrm{mL}$ ), dried over $\mathrm{MgSO}_{4}$, and evaporated in vacuo. To a suspension of $\mathrm{NaBH}_{4}(35.0 \mathrm{~g}, 926 \mathrm{mmol})$ and $\mathrm{LiCl}(39.3 \mathrm{~g}$, $926 \mathrm{mmol}$ ) in $800 \mathrm{~mL}$ of ethanol cooled to $0{ }^{\circ} \mathrm{C}$, a solution of the crude in $190 \mathrm{~mL}$ of ethanol is added slowly. The reaction is stirred at $0{ }^{\circ} \mathrm{C}$ for $10 \mathrm{~min}$, at room temperature for $30 \mathrm{~min}$, and at $50{ }^{\circ} \mathrm{C}$ for $2.5 \mathrm{~h}$. The reaction is cooled to $0{ }^{\circ} \mathrm{C}$, and a saturated solution of $\mathrm{NH}_{4} \mathrm{Cl}$ is added (until salts are dissolved, $450 \mathrm{~mL})$. The aqueous layer is extracted with AcOEt $(3 \times 350$ $\mathrm{mL})$. The combined organic layers are washed with brine $(200$ $\mathrm{mL}$ ), dried over $\mathrm{MgSO}_{4}$, and evaporated in vacuo. The reaction crude is filtered through a pad of silica gel using Hex/AcOEt (19:1) to Hex/AcOEt $(1: 1)$ as eluents. A colorless oil is obtained (123.2 g, 85\% after two steps). ${ }^{1} \mathrm{H}$ NMR (400 MHz, $\left.\mathrm{CDCl}_{3}\right) \delta 5.14$ (brs, $\left.1 \mathrm{H}, \mathrm{NH}\right), 3.86-3.66\left(\mathrm{~m}, 5 \mathrm{H}, 2 \times \mathrm{CH}_{2} \mathrm{O}\right.$ $+\mathrm{CH}), 2.70($ brs, $1 \mathrm{H}, \mathrm{OH}), 1.45\left(\mathrm{~s}, 9 \mathrm{H}, 3 \times \mathrm{CH}_{3}\right), 0.90(\mathrm{~s}$, $\left.9 \mathrm{H}, 3 \times \mathrm{CH}_{3}\right), 0.08\left(\mathrm{~s}, 6 \mathrm{H}, 2 \times \mathrm{CH}_{3} \mathrm{Si}\right) .{ }^{13} \mathrm{C} \mathrm{NMR}(100 \mathrm{MHz}$, $\left.\mathrm{CDCl}_{3}\right) \delta 156.1,79.6,64.0$ (2C), 52.7, 28.5 (3C), 25.9 (3C), $18.3,-5.5$ (2C). IR (NaCl): 3371, 2952, 2861, $1707 \mathrm{~cm}^{-1}$. $[\alpha]_{\mathrm{D}}{ }^{25}(c \quad 0.28$ in DCM $):+9.30$. Found: C, 55.1, H, $10.4 \%$. Calc. for $\mathrm{C}_{14} \mathrm{H}_{31} \mathrm{NO}_{4} \mathrm{Si}$ : C, 55.0; $\mathrm{H}, 10.2 \%$.

(R)-4-(((tert-Butyldimethylsilyl)oxy)methyl)oxazolidin-2one. To a suspension of $\mathrm{NaH} 60 \% \mathrm{w} / \mathrm{w}(18.9 \mathrm{~g}, 472 \mathrm{mmol})$ in $300 \mathrm{~mL}$ of THF cooled to $0{ }^{\circ} \mathrm{C}$ is added a solution of $\mathbf{1}(123.2$ g, $403 \mathrm{mmol}$ ) in $550 \mathrm{~mL}$ of THF. The reaction is stirred at 0 ${ }^{\circ} \mathrm{C}$ for $15 \mathrm{~min}$, at room temperature for $25 \mathrm{~min}$, and at $40{ }^{\circ} \mathrm{C}$ for $2.5 \mathrm{~h}$. The reaction is cooled down to $0{ }^{\circ} \mathrm{C}$, and a saturated solution of $\mathrm{NH}_{4} \mathrm{Cl}$ is added until all salts are dissolved $(250$ $\mathrm{mL})$. The aqueous layer is extracted with AcOEt $(2 \times 500$ $\mathrm{mL}$ ). The combined organic layers are washed with brine (300 $\mathrm{mL}$ ), dried over $\mathrm{MgSO}_{4}$, and evaporated in vacuo. A colorless wax is obtained $(78.9 \mathrm{~g}, 72 \%) .{ }^{1} \mathrm{H} \mathrm{NMR}\left(400 \mathrm{MHz}, \mathrm{CDCl}_{3}\right) \delta$ 6.27 (brs, $1 \mathrm{H}, \mathrm{NH}), 4.42\left(\mathrm{t}, J=8.6 \mathrm{~Hz}, 1 \mathrm{H}, \mathrm{CH}_{2} \mathrm{O}\right), 4.18$ (dd, $\left.J=8.8,4.8 \mathrm{~Hz}, 1 \mathrm{H}, \mathrm{CH}_{2} \mathrm{O}\right), 3.94-3.88(\mathrm{~m}, 1 \mathrm{H}, \mathrm{CH}), 3.60(\mathrm{~d}$, $\left.J=5.4 \mathrm{~Hz}, 2 \mathrm{H}, \mathrm{CH}_{2} \mathrm{OSi}\right), 0.87\left(\mathrm{~s}, 9 \mathrm{H}, 3 \times \mathrm{CH}_{3}\right), 0.05(\mathrm{~s}, 6 \mathrm{H}$, $\left.2 \times \mathrm{CH}_{3} \mathrm{Si}\right) \cdot{ }^{13} \mathrm{C} \mathrm{NMR}\left(100 \mathrm{MHz}, \mathrm{CDCl}_{3}\right) \delta 160.2,67.3,64.8$, 53.8, 25.9 (3C), 18.3, -5.4 (2C). IR ( NaCl): 3315, 2959, 2848, $1745 \mathrm{~cm}^{-1}$. $[\alpha]_{\mathrm{D}}{ }^{25}$ (c 0.32 in DCM): -15.94 . Found: C, 52.2, $\mathrm{H}, 9.0 \%$. Calc. for $\mathrm{C}_{10} \mathrm{H}_{21} \mathrm{NO}_{3} \mathrm{Si}$ : C, 51.9; $\mathrm{H}, 9.2 \%$.

(R)-3-Allyl-4-(((tert-butyldimethylsilyl)oxy)methyl)oxazolidin-2-one (2). To a suspension of $\mathrm{NaH} 60 \% \mathrm{w} / \mathrm{w}(16.4$ $\mathrm{g}, 409.1 \mathrm{mmol})$ in $500 \mathrm{~mL}$ of THF at $0{ }^{\circ} \mathrm{C}$, a solution of $(R)-4-$
(( tert-butyldimethylsilyl)oxy)methyl)oxazolidin-2-one (78.9 g, $340.9 \mathrm{mmol})$ in $500 \mathrm{~mL}$ of THF is added slowly. Allyl bromide $(29.5 \mathrm{~mL}, 340.9 \mathrm{mmol})$ is added and stirred for 15 $\mathrm{min}$ at $0{ }^{\circ} \mathrm{C}, 30 \mathrm{~min}$ at room temperature, and $2 \mathrm{~h}$ at $50{ }^{\circ} \mathrm{C}$. A saturated solution of $\mathrm{NH}_{4} \mathrm{Cl}$ is added until the salts are dissolved. The aqueous layer is extracted with AcOEt $(3 \times 200$ $\mathrm{mL})$. The combined organic layers are washed with brine (150 $\mathrm{mL}$ ) and dried over $\mathrm{MgSO}_{4}$. The solvent is evaporated in $v a c u o$, and the residue is filtered through a pad of silica gel using $\mathrm{Hex} / \mathrm{AcOEt}(19: 1)$ to $\mathrm{Hex} / \mathrm{AcOEt}(1: 1)$ as eluents. A yellow oil is obtained (64.8 g, 70\%). ${ }^{1} \mathrm{H}$ NMR (400 MHz, $\left.\mathrm{CDCl}_{3}\right) \delta$ 5.84-5.74 (m, 1H, HC=), 5.27-5.21 (m, $2 \mathrm{H}$, $\left.\mathrm{H}_{2} \mathrm{C}=\right), 4.33\left(\mathrm{t}, J=8.7 \mathrm{~Hz}, 1 \mathrm{H}, \mathrm{CH}_{2} \mathrm{O}\right), 4.18-4.13(\mathrm{~m}, 2 \mathrm{H}$, $\left.\mathrm{CH}_{2} \mathrm{O}+\mathrm{CH}_{2} \mathrm{~N}\right), 3.86-3.80(\mathrm{~m}, 1 \mathrm{H}, \mathrm{CH}), 3.69-3.62(\mathrm{~m}, 3 \mathrm{H}$, $\left.\mathrm{CH}_{2} \mathrm{OSi}+\mathrm{CH}_{2} \mathrm{~N}\right), 0.89\left(\mathrm{~s}, 9 \mathrm{H}, 3 \times \mathrm{CH}_{3}\right), 0.06(\mathrm{~s}, 6 \mathrm{H}, 2 \times$ $\left.\mathrm{CH}_{3} \mathrm{Si}\right) .{ }^{13} \mathrm{C} \mathrm{NMR}\left(100 \mathrm{MHz}, \mathrm{CDCl}_{3}\right) \delta 158.4,132.7,118.5$, 65.0, 62.2, 56.0, 45.3, 25.9 (3C), 18.3, -5.4 (2C). IR ( NaCl): 3084, 2948, 2866, $1744 \mathrm{~cm}^{-1}$. $[\alpha]_{\mathrm{D}}^{25}$ (c 0.21 in $\left.\mathrm{CHCl}_{3}\right)$ : -11.84 . Found: C, 57.1, H, 9.1\%. Calc. for $\mathrm{C}_{13} \mathrm{H}_{25} \mathrm{NO}_{3} \mathrm{Si}: \mathrm{C}$, $57.5 ; \mathrm{H}, 9.3 \%$.

(S)-3-Allyl-4-(hydroxymethyl)oxazolidin-2-one. To a solution of 2 (55.5 g, $204.6 \mathrm{mmol})$ in $220 \mathrm{~mL}$ of THF is added TBAF. $3 \mathrm{H}_{2} \mathrm{O}(58.8 \mathrm{~g}, 225.0 \mathrm{mmol})$. The mixture is stirred for $30 \mathrm{~min}$ at room temperature. The solvent is evaporated in vacuo and filtered through a pad of silica gel using Hex/AcOEt $(2: 1)$ to $\mathrm{Hex} / \mathrm{AcOEt}(1: 2)$ as eluents. A colorless oil is obtained (28.9 g, 90\%). ${ }^{1} \mathrm{H}$ NMR (400 MHz, $\left.\mathrm{CDCl}_{3}\right) \delta 5.86-$ $5.76(\mathrm{~m}, 1 \mathrm{H}, \mathrm{HC}=)$, 5.30-5.24 (m, $\left.2 \mathrm{H}, \mathrm{H}_{2} \mathrm{C}=\right)$, $4.36(\mathrm{t}, J=$ $\left.8.8 \mathrm{~Hz}, 1 \mathrm{H}, \mathrm{CH}_{2} \mathrm{O}\right), 4.25\left(\mathrm{dd}, J=8.7,6.0 \mathrm{~Hz}, 1 \mathrm{H}, \mathrm{CH}_{2} \mathrm{O}\right)$, 4.09 (ddt, $\left.J=15.7,5.3,1.6 \mathrm{~Hz}, 1 \mathrm{H}, \mathrm{CH}_{2} \mathrm{~N}\right), 3.90-3.84(\mathrm{~m}$, $1 \mathrm{H}, \mathrm{CHN}), 3.80-3.73\left(\mathrm{~m}, 2 \mathrm{H}, \mathrm{CH}_{2} \mathrm{~N}+\mathrm{CH}_{2} \mathrm{OH}\right), 3.65$ (dd, $J$ $\left.=11.9,3.3 \mathrm{~Hz}, 1 \mathrm{H}, \mathrm{CH}_{2} \mathrm{OH}\right) .{ }^{13} \mathrm{C} \mathrm{NMR}\left(100 \mathrm{MHz} \mathrm{CDCl}_{3}\right) \delta$ 158.7, 132.5, 118.9, 64.7, 60.9, 56.3, 45.4. IR ( NaCl): 3427, $3048,2975,2851,1753 \mathrm{~cm}^{-1}$. $[\alpha]_{\mathrm{D}}{ }^{25}\left(0.25\right.$ in $\left.\mathrm{CHCl}_{3}\right):-44.28$. Found: C, 53.8; H, 7.3\%. Calc. for $\mathrm{C}_{7} \mathrm{H}_{11} \mathrm{NO}_{3}$ : C, 53.5; $\mathrm{H}$, $7.1 \%$.

(R)-3-Allyl-2-oxo-oxazolidine-4-carboxylic Acid (3). A solution of (S)-3-allyl-4-(hydroxymethyl)oxazolidin-2-one $(28.9 \mathrm{~g}, 184.1 \mathrm{mmol})$ in $1 \mathrm{~L}$ of acetone is cooled to $0{ }^{\circ} \mathrm{C}$, and $92 \mathrm{~mL}$ of Jones' reagent is added slowly. The reaction is stirred for $1.5 \mathrm{~h}$ at $0{ }^{\circ} \mathrm{C}$. Isopropanol is added until the solution turns blue. The mixture is filtered through a pad of celite. The solvent is evaporated in vacuo and the residue is filtered through a pad of silica gel using Hex/AcOEt (1:1) to AcOEt $100 \%$ as eluents. A pale yellow oil is obtained $(23.0 \mathrm{~g}, 73 \%)$. ${ }^{1} \mathrm{H}$ NMR (400 MHz, $\mathrm{CDCl}_{3}$ ) $\delta 9.83$ (brs, $1 \mathrm{H}, \mathrm{OH}$ ), 5.80-5.70 $(\mathrm{m}, 1 \mathrm{H}, \mathrm{HC}=)$, 5.27-5.24 (m, $\left.2 \mathrm{H}, \mathrm{H}_{2} \mathrm{C}=\right), 4.52(\mathrm{t}, J=9.4$ $\mathrm{Hz}, 1 \mathrm{H}, \mathrm{CH}_{2} \mathrm{O}$ ), 4.42 (dd, $J=9.0,4.5 \mathrm{~Hz}, 1 \mathrm{H}, \mathrm{CH}_{2} \mathrm{O}$ ), 4.36 (dd, $J=9.7,4.6 \mathrm{~Hz}, 1 \mathrm{H}, \mathrm{CHN}), 4.27$ (dd, $J=15.4,4.8 \mathrm{~Hz}, 1 \mathrm{H}$, $\mathrm{CH}_{2} \mathrm{~N}$ ), $3.75\left(\mathrm{dd}, J=15.4,8.0 \mathrm{~Hz}, 1 \mathrm{H}, \mathrm{CH}_{2} \mathrm{~N}\right) .{ }^{13} \mathrm{C} \mathrm{NMR}$ $\left(100 \mathrm{MHz}, \mathrm{CDCl}_{3}\right) \delta 172.3,158.5,131.0,120.1,65.1,56.0$, 46.0. IR $(\mathrm{NaCl}): 3454,2933,2839,1731 \mathrm{~cm}^{-1} \cdot[\alpha]_{\mathrm{D}}^{25}(0.30 \mathrm{in}$ $\left.\mathrm{CHCl}_{3}\right)$ : +8.98. Found: C, 48.8; $\mathrm{H}, 5.4 \%$. Calc. for $\mathrm{C}_{7} \mathrm{H}_{9} \mathrm{NO}_{4}$ : C, $49.1 ; \mathrm{H}, 5.3 \%$.

(R)-3-Allyl-N-methoxy-N-methyl-2-oxo-oxazolidine-4-carboxamide (4). A solution of $3(23.0 \mathrm{~g}, 134.4 \mathrm{mmol})$ in $500 \mathrm{~mL}$ of DCM is cooled to $0{ }^{\circ} \mathrm{C}$. Diisopropylethylamine (DIPEA; $23.5 \mathrm{~mL}, 134.4 \mathrm{mmol})$, EDCI (25.8 g, $134.4 \mathrm{mmol})$, and $\mathrm{N}, \mathrm{O}-$ dimethylhydroxylamine hydrochloride $(13.1 \mathrm{~g}, 134.4 \mathrm{mmol})$ are added. The reaction is stirred for $2 \mathrm{~h}$ at $0{ }^{\circ} \mathrm{C}$. The solvent is evaporated in vacuo and filtered through a pad of silica gel using $\mathrm{Hex} / \mathrm{AcOEt}(1: 4)$ as the eluent. A yellow oil is obtained (25.3 g, 88\%). ${ }^{1} \mathrm{H}$ NMR (400 MHz, $\mathrm{CDCl}_{3}$ ) $\delta 5.83-5.73(\mathrm{~m}$, 
$1 \mathrm{H}, \mathrm{HC}=)$, 5.25-5.21 (m, 2H, $\left.\mathrm{H}_{2} \mathrm{C}=\right)$, $4.66(\mathrm{dd}, J=9.8,5.6$ $\mathrm{Hz}, 1 \mathrm{H}, \mathrm{CHN}), 4.50\left(\mathrm{t}, J=9.3 \mathrm{~Hz}, 1 \mathrm{H}, \mathrm{CH}_{2} \mathrm{O}\right), 4.32(\mathrm{ddt}, J=$ $\left.15.4,4.7,1.7 \mathrm{~Hz}, 1 \mathrm{H}, \mathrm{CH}_{2} \mathrm{~N}\right), 4.18(\mathrm{dd}, J=8.8,5.6 \mathrm{~Hz}, 1 \mathrm{H}$, $\mathrm{CH}_{2} \mathrm{O}$ ), 3.69 (s, $3 \mathrm{H}, \mathrm{OCH}_{3}$ ), 3.68 (dd, $J=15.4,8.3 \mathrm{~Hz}, 1 \mathrm{H}$, $\left.\mathrm{CH}_{2} \mathrm{~N}\right), 3.22\left(\mathrm{~s}, 3 \mathrm{H}, \mathrm{NCH}_{3}\right) .{ }^{13} \mathrm{C}$ NMR $\left(100 \mathrm{MHz} \mathrm{CDCl}_{3}\right) \delta$ $169.6,158.0,132.2,119.3,64.5,61.7,54.8,45.9,32.7$. IR $(\mathrm{NaCl}): 3088,2979,2928,1754,1672 \mathrm{~cm}^{-1} \cdot[\alpha]_{\mathrm{D}}{ }^{25}(c 0.37$ in DCM): +31.11. Found: C, 50.4; H, 6.9\%. Calc. for $\mathrm{C}_{9} \mathrm{H}_{14} \mathrm{~N}_{2} \mathrm{O}_{4}$ : C, 50.5; $\mathrm{H}, 6.6 \%$.

(R)-4-Acryloyl-3-allyloxazolidin-2-one. To a solution of 4 ( $12.0 \mathrm{~g}, 56.0 \mathrm{mmol}$ ) in $270 \mathrm{~mL}$ of THF cooled to $-30{ }^{\circ} \mathrm{C}, 0.7$ $\mathrm{M}$ vinylmagnesium bromide $(200 \mathrm{~mL})$ is added slowly, keeping the temperature below $-25{ }^{\circ} \mathrm{C}$. When the addition is finished, the reaction is stirred for another $30 \mathrm{~min}$ at $-30{ }^{\circ} \mathrm{C}$. The reaction mixture is poured into a mixture of $200 \mathrm{~mL}$ of $\mathrm{HCl} 10 \%$ and $100 \mathrm{~mL}$ of $\mathrm{MeOH}$ cooled in a bath at $-15^{\circ} \mathrm{C}$. This mixture is stirred for another $15 \mathrm{~min}$. The aqueous layer is extracted with AcOEt $(3 \times 150 \mathrm{~mL})$. The combined organic layers are washed with a solution of $1 \mathrm{M} \mathrm{HCl}(200 \mathrm{~mL})$, with a saturated solution of $\mathrm{NaHCO}_{3}(150 \mathrm{~mL})$ and brine $(150 \mathrm{~mL})$, dried over $\mathrm{MgSO}_{4}$, and evaporated in vacuo. The crude is used without further purification. ${ }^{1} \mathrm{H}$ NMR $\left(400 \mathrm{MHz} \mathrm{CDCl}_{3}\right) \delta$ $6.50(\mathrm{dd}, J=17.5,10.4 \mathrm{~Hz}, 1 \mathrm{H},=\mathrm{CHCO}), 6.39$ (d, $J=17.4$ $\mathrm{Hz}, 1 \mathrm{H}, \mathrm{H}_{2} \mathrm{C}=\mathrm{CHCO}$, trans), $6.01\left(\mathrm{~d}, J=10.4 \mathrm{~Hz}, 1 \mathrm{H}, \mathrm{H}_{2} \mathrm{C}\right.$ $=\mathrm{CHCO}$, cis $), 5.78-5.68(\mathrm{~m}, 1 \mathrm{H}, \mathrm{HC}=), 5.24-5.16(\mathrm{~m}$, $\left.2 \mathrm{H}, \mathrm{H}_{2} \mathrm{C}=\right), 4.59(\mathrm{dd}, J=10.0,5.2 \mathrm{~Hz}, 1 \mathrm{H}, \mathrm{CHN}), 4.52(\mathrm{t}, J$ $\left.=9.3 \mathrm{~Hz}, 1 \mathrm{H}, \mathrm{CH}_{2} \mathrm{O}\right), 4.26\left(\mathrm{dd}, J=15.3,4.6 \mathrm{~Hz}, 1 \mathrm{H}, \mathrm{CH}_{2} \mathrm{~N}\right)$, $4.15\left(\mathrm{dd}, J=8.6,5.2 \mathrm{~Hz}, 1 \mathrm{H}, \mathrm{CH}_{2} \mathrm{O}\right), 3.59$ (dd, $J=15.3,8.0$ $\left.\mathrm{Hz}, 1 \mathrm{H}, \mathrm{CH}_{2} \mathrm{~N}\right) .{ }^{13} \mathrm{C} \mathrm{NMR}\left(100 \mathrm{MHz}, \mathrm{CDCl}_{3}\right) \delta 195.1,157.7$, 132.3, 131.8, 131.4, 120.1, 63.8, 60.5, 46.2.

(R)-1,8a-Dihydro-3H-oxazolo[3,4-a]pyridine-3,8(5H)dione (5). The crude of the previous reaction is dissolved in $180 \mathrm{~mL}$ of DCM and heated to reflux. Grubb's secondgeneration catalyst is added $(1.2 \mathrm{~g}, 1.4 \mathrm{mmol})$. The reaction is stirred under reflux for $1.5 \mathrm{~h}$. The solvent is evaporated in vacuo. The crude is purified in silica gel in Hex/AcOEt (1:1). A brown oil is obtained ( $5.6 \mathrm{~g}$, 65\% after two steps). ${ }^{1} \mathrm{H}$ NMR $\left(400 \mathrm{MHz}, \mathrm{CDCl}_{3}\right) \delta 7.06$ (ddd, $J=10.5,4.4,2.0 \mathrm{~Hz}, 1 \mathrm{H},=$ $\left.\mathrm{CHCH}_{2}\right), 6.26(\mathrm{dt}, J=10.5,2.3 \mathrm{~Hz}, 1 \mathrm{H},=\mathrm{CHCO}), 4.69(\mathrm{dd}$, $J=9.0,4.4 \mathrm{~Hz}, 1 \mathrm{H}, \mathrm{CHN}), 4.61-4.50\left(\mathrm{~m}, 2 \mathrm{H}, \mathrm{CH}_{2} \mathrm{O}+\right.$ $\mathrm{CH}_{2} \mathrm{~N}$ ), 4.27 (ddd, $\left.J=9.4,4.4,2.1 \mathrm{~Hz}, 1 \mathrm{H}, \mathrm{CH}_{2} \mathrm{O}\right), 4.02(\mathrm{dq}, J$ $\left.=20.5,2.3 \mathrm{~Hz}, 1 \mathrm{H}, \mathrm{CH}_{2} \mathrm{~N}\right) \cdot{ }^{13} \mathrm{C} \mathrm{NMR}\left(100 \mathrm{MHz}^{\mathrm{C}} \mathrm{CDCl}_{3}\right) \delta$ 192.1, 157.4, 146.5, 127.7, 64.2, 57.9, 41.8. IR ( $\mathrm{NaCl}): 3081$, 2959, 2920, 2854, 1752, $1748 \mathrm{~cm}^{-1}$. $[\alpha]_{\mathrm{D}}{ }^{25}$ (c 0.09 in DCM): +65.02. Found: C, 55.1; $\mathrm{H}, 4.5 \%$. Calc. for $\mathrm{C}_{7} \mathrm{H}_{7} \mathrm{NO}_{3}$ : C, 54.9; $\mathrm{H}, 4.6 \%$.

tert-Butyl (5aR,6S,6aS,7aR)-3,7-Dioxohexahydro-1H,3Hcyclopropa[d]oxazolo[3,4-a]pyridine-6-carboxylate (6). To a solution of $5(2.4 \mathrm{~g}, 15.9 \mathrm{mmol})$ in $13 \mathrm{~mL}$ of DCM at $0{ }^{\circ} \mathrm{C}$ is added a solution of tert-butyl (tetrahydrothiophenylidene)acetate $(9.6 \mathrm{~g}, 47.6 \mathrm{mmol})$ in $207 \mathrm{~mL}$ of DCM slowly. The reaction is stirred at room temperature for $30 \mathrm{~min}$. Deionized water $(20 \mathrm{~mL})$ is added. The aqueous layer is extracted with DCM $(2 \times 30 \mathrm{~mL})$. The combined organic phases are washed with brine $(20 \mathrm{~mL})$, dried over $\mathrm{MgSO}_{4}$, and evaporated in vacuo. The crude is purified in silica gel using $\mathrm{Hex} / \mathrm{AcOEt}$ (2:1) as the eluent. A yellow wax is obtained $(3.0 \mathrm{~g}, 70 \%) .{ }^{1} \mathrm{H}$ NMR $\left(400 \mathrm{MHz}, \mathrm{CDCl}_{3}\right) \delta 4.53\left(\mathrm{t}, J=9.7 \mathrm{~Hz}, 1 \mathrm{H}, \mathrm{CH}_{2} \mathrm{O}\right)$, 4.32 (dd, $\left.J=9.3,5.7 \mathrm{~Hz}, 1 \mathrm{H}, \mathrm{CH}_{2} \mathrm{O}\right), 4.23(\mathrm{~d}, J=14.1 \mathrm{~Hz}, 1 \mathrm{H}$, $\left.\mathrm{CH}_{2} \mathrm{~N}\right), 4.04(\mathrm{dd}, J=10.3,5.7 \mathrm{~Hz}, 1 \mathrm{H}, \mathrm{CHN}), 3.53(\mathrm{~d}, J=$ $14.0 \mathrm{~Hz}, 1 \mathrm{H}, \mathrm{CH}_{2} \mathrm{~N}$ ), 2.39 (dd, $J=7.9,4.2 \mathrm{~Hz}, 1 \mathrm{H}, \mathrm{CHCO}$ ), 2.21-2.18(m, 1H, $\left.\mathrm{CHCH}_{2} \mathrm{~N}\right) 2.10(\mathrm{t}, J=4.5 \mathrm{~Hz}, 1 \mathrm{H}$, $\left.\mathrm{CHCO}_{2}\right), 1.44\left(\mathrm{~s}, 9 \mathrm{H}, 3 \times \mathrm{CH}_{3}\right) \cdot{ }^{13} \mathrm{C} \mathrm{NMR}(100 \mathrm{MHz}$,
$\left.\mathrm{CDCl}_{3}\right) \delta 200.0,168.9,156.9,82.8,64.2,58.8,37.2,31.6,28.1$, 24.5, 22.7. IR (NaCl): 2975, 2863, 1748, $1736,1719 \mathrm{~cm}^{-1}$. $[\alpha]_{\mathrm{D}}{ }^{25}$ (c 0.11 in DCM): +38.02. Found: C, 58.0; H, 4.9\%. Calc. for $\mathrm{C}_{13} \mathrm{H}_{17} \mathrm{NO}_{5}$ : C, 58.4; $\mathrm{H}, 4.6 \%$.

tert-Butyl (5aR,6S,6aS,7S,7aR) and tert-butyl (5aR,6S, 6aS, 7R,7aR)-7-Hydroxy-3-oxohexahydro-1 H, 3Hcyclopropa[d]oxazolo[3,4-a]pyridine-6-carboxylate (7a and 7b). To a solution of $6(1.1 \mathrm{~g}, 4.1 \mathrm{mmol})$ in $35 \mathrm{~mL}$ of absolute ethanol at $0{ }^{\circ} \mathrm{C}$ is added $\mathrm{NaBH}_{4}(312 \mathrm{mg}, 8.2 \mathrm{mmol})$. The reaction is stirred for $1 \mathrm{~h}$ at room temperature. A solution of saturated $\mathrm{NH}_{4} \mathrm{Cl}(20 \mathrm{~mL})$ and water (until salts dissolve) is added. The aqueous phase is extracted with AcOEt $(3 \times 60$ $\mathrm{mL})$. The combined organic layers are washed with brine $(50$ $\mathrm{mL}$ ), dried over $\mathrm{MgSO}_{4}$, and evaporated in vacuo. The crude contained a $3: 2$ mixture of isomers $7 \mathbf{a} / 7 \mathbf{b}$ as determined by the integration of signals in the ${ }^{1} \mathrm{H}$ NMR spectrum of the reaction crude. This mixture was separated by silica gel chromatography using $\mathrm{Hex} / \mathrm{AcOEt}(1: 1)$ to $\mathrm{Hex} / \mathrm{AcOEt}(1: 2)$ as eluents. A yellow wax is obtained for isomer $7 \mathrm{a}(463 \mathrm{mg}, 42 \%)$. A yellow solid is obtained for isomer $7 \mathbf{b}$ (330 mg, 30\%).

Spectroscopic data for tert-butyl ( $5 \mathrm{a}, 6 S, 6 \mathrm{a} S, 7 S, 7 \mathrm{a} R)-7$ hydroxy-3-oxohexahydro- $1 \mathrm{H}, 3 \mathrm{H}$-cyclopropa $[d]$ oxazolo[3,4-a]pyridine-6-carboxylate $7 \mathrm{a}:{ }^{1} \mathrm{H}$ NMR $\left(400 \mathrm{MHz}, \mathrm{CDCl}_{3}\right) \delta 4.52$ $\left(\mathrm{t}, J=8.6 \mathrm{~Hz}, 1 \mathrm{H}, \mathrm{CH}_{2} \mathrm{O}\right), 4.12(\mathrm{dd}, J=9.1,4.8 \mathrm{~Hz}, 1 \mathrm{H}$, $\left.\mathrm{CH}_{2} \mathrm{O}\right), 4.00\left(\mathrm{~d}, J=13.6 \mathrm{~Hz}, 1 \mathrm{H}, \mathrm{CH}_{2} \mathrm{~N}\right), 3.80(\mathrm{dd}, J=8.5$, $4.5 \mathrm{~Hz}, 1 \mathrm{H}, \mathrm{CHOH}), 3.40\left(\mathrm{dd}, J=13.6,4.1 \mathrm{~Hz}, 1 \mathrm{H}, \mathrm{CH}_{2} \mathrm{~N}\right)$, $3.33(\mathrm{td}, J=8.3,4.9 \mathrm{~Hz}, 1 \mathrm{H}, \mathrm{CHN}), 2.41(\mathrm{~d}, J=5.0 \mathrm{~Hz}, 1 \mathrm{H}$, $\mathrm{OH}), 1.76-1.70\left(\mathrm{~m}, 1 \mathrm{H}, \mathrm{CHCH}_{2} \mathrm{~N}\right), 1.67(\mathrm{dd}, J=9.1,5.0 \mathrm{~Hz}$, $1 \mathrm{H}, \mathrm{CHCHOH}), 1.44\left(\mathrm{~s}, 9 \mathrm{H}, 3 \times \mathrm{CH}_{3}\right), 1.40(\mathrm{t}, J=4.9 \mathrm{~Hz}$, $\left.1 \mathrm{H}, \mathrm{CHCO}_{2}\right) .{ }^{13} \mathrm{C} \mathrm{NMR}\left(100 \mathrm{MHz}, \mathrm{CDCl}_{3}\right) \delta 172.2,157.5$, $81.4,69.0,68.3,56.8,38.5,28.2$ (3C), 27.3, 24.5, 20.3. IR $(\mathrm{NaCl}): 3361,2975,2863,1748,1736 \mathrm{~cm}^{-1} \cdot[\alpha]_{\mathrm{D}}{ }^{25}(c 0.14$ in DCM): -2.20 . Found: C, 58.2; $\mathrm{H}, 6.8 \%$. Calc. for $\mathrm{C}_{13} \mathrm{H}_{19} \mathrm{NO}_{5}$ : C, 58.0; H, 7.1\%.

Spectroscopic data for tert-butyl (5aR,6S,6aS,7R,7aR)-7hydroxy-3-oxohexahydro- $1 H, 3 H$-cyclopropa $[d]$ oxazolo[3,4-a]pyridine-6-carboxylate $7 \mathbf{b}:{ }^{1} \mathrm{H}$ NMR $\left(400 \mathrm{MHz} \mathrm{CDCl}_{3}\right) \delta$ $4.54\left(\mathrm{dd}, J 08.5,6.4 \mathrm{~Hz}, 1 \mathrm{H}, \mathrm{CH}_{2} \mathrm{O}\right), 4.29(\mathrm{t}, J=8.8 \mathrm{~Hz}, 1 \mathrm{H}$, $\left.\mathrm{CH}_{2} \mathrm{O}\right), 4.24-4.20(\mathrm{~m}, 1 \mathrm{H}, \mathrm{CHOH}), 4.00(\mathrm{~d}, J=13.4 \mathrm{~Hz}, 1 \mathrm{H}$, $\mathrm{CH}_{2} \mathrm{~N}$ ), 3.61-3.55 (m, 1H, CHN), $3.29(\mathrm{dd}, J=13.4,4.0 \mathrm{~Hz}$, $\left.1 \mathrm{H}, \mathrm{CH}_{2} \mathrm{~N}\right), 2.11(\mathrm{td}, J=8.4,5.0 \mathrm{~Hz}, 1 \mathrm{H}, \mathrm{CHCHOH}), 1.97$ $(\mathrm{d}, J=4.1 \mathrm{~Hz}, 1 \mathrm{H}, \mathrm{OH}), 1.84-1.74(\mathrm{~m}, 2 \mathrm{H}, 2 \times \mathrm{CH}$ cyclopropane), $1.44\left(\mathrm{~s}, 9 \mathrm{H}, 3 \times \mathrm{CH}_{3}\right) .{ }^{13} \mathrm{C}$ NMR $(100 \mathrm{MHz}$, $\left.\mathrm{CDCl}_{3}\right) \delta 172.1,157.8,81.5,63.1,60.4,55.7,38.8,28.3(3 \mathrm{C})$, 25.9, 21.2, 20.5. IR (KBr): 3361, 2975, 2863, 1748, $1736 \mathrm{~cm}^{-1}$. $[\alpha]_{\mathrm{D}}{ }^{25}$ (c 0.04 in DCM): -10.46 . Found: C, $58.3 ; \mathrm{H}, 7.0 \%$. Calc. for $\mathrm{C}_{13} \mathrm{H}_{19} \mathrm{NO}_{5}: \mathrm{C}, 58.0 ; \mathrm{H}, 7.1 \% . \mathrm{Mp}>180.0{ }^{\circ} \mathrm{C}$, dec.

(5aR,6S,6aS,7S,7aR)-7-Hydroxy-3-oxohexahydro- $1 \mathrm{H}, 3 \mathrm{H}$ cyclopropa[d]oxazolo[3,4-a]pyridine-6-carboxylic Acid. To a solution of $7 \mathrm{a}(250 \mathrm{mg}, 0.9 \mathrm{mmol})$ in $1.5 \mathrm{~mL}$ of DCM is added $9.3 \mathrm{~mL}$ of TFA at room temperature. The reaction is stirred for $30 \mathrm{~min}$. The solvent is evaporated in vacuo. Toluene is added until all TFA is evaporated. The crude is purified in silica gel in $10 \% \mathrm{DCM} / \mathrm{MeOH}$. A brown wax is obtained (187 mg, 94\%). ${ }^{1} \mathrm{H}$ NMR (400 MHz, MeOD) $\delta 4.54(\mathrm{t}, J=8.5 \mathrm{~Hz}, 1 \mathrm{H}$, $\mathrm{CH}_{2} \mathrm{O}$ ), $4.14\left(\mathrm{dd}, J=8.9,5.2 \mathrm{~Hz}, 1 \mathrm{H}, \mathrm{CH}_{2} \mathrm{O}\right), 3.87(\mathrm{~d}, J=$ $13.6 \mathrm{~Hz}, 1 \mathrm{H}, \mathrm{CH}_{2} \mathrm{~N}$ ), 3.82 (d, J = 8.7 Hz, 1H, CHOH), 3.44 (dd, $\left.J=13.5,4.2 \mathrm{~Hz}, 1 \mathrm{H}, \mathrm{CH}_{2} \mathrm{~N}\right), 3.37(\mathrm{td}, J=8.5,5.2 \mathrm{~Hz}, 1 \mathrm{H}$, CHN), $1.84-1.75\left(\mathrm{~m}, 1 \mathrm{H}, \mathrm{CHCH}_{2} \mathrm{~N}\right), 1.70(\mathrm{dd}, J=9.3,4.7$ $\mathrm{Hz}, 1 \mathrm{H}, \mathrm{CHCHOH}), 1.38$ (brs, $\left.1 \mathrm{H}, \mathrm{CHCO}_{2}\right) .{ }^{13} \mathrm{C}$ NMR $(100$ $\left.\mathrm{MHz}, \mathrm{D}_{2} \mathrm{O}\right) \delta 176.6,159.5,69.8,69.6,58.2,39.5,29.0,24.5$, 21.9. IR $(\mathrm{NaCl}): 3396,2984,2851,1748,1729 \mathrm{~cm}^{-1} \cdot[\alpha]_{\mathrm{D}}{ }^{25}(c$ 
0.05 in $\mathrm{MeOH}$ ): -3.68. Found: C, 51.1; H, 5.3\%. Calc. for $\mathrm{C}_{9} \mathrm{H}_{11} \mathrm{NO}_{5}$ : C, 50.7; $\mathrm{H}, 5.2 \%$.

(5aR,6S,6aS,7R,7aR)-7-Hydroxy-3-oxohexahydro-1H,3Hcyclopropa[d]oxazolo[3,4-a]pyridine-6-carboxylic Acid. To a solution of $7 \mathbf{b}(86 \mathrm{mg}, 0.3 \mathrm{mmol})$ in $1 \mathrm{~mL}$ of DCM is added $3.2 \mathrm{~mL}$ of TFA at room temperature. The reaction is stirred for $30 \mathrm{~min}$. The solvent is evaporated in vacuo. Toluene is added until all TFA is evaporated. The crude is purified in silica gel in $10 \% \mathrm{DCM} / \mathrm{MeOH}$. A brown wax is obtained (60 mg, 90\%). ${ }^{1} \mathrm{H}$ NMR $\left(400 \mathrm{MHz}, \mathrm{D}_{2} \mathrm{O}\right) \delta 4.47(\mathrm{dd}, J=8.5,5.8 \mathrm{~Hz}, 1 \mathrm{H}$, $\mathrm{CH}_{2} \mathrm{O}$ ), $4.31\left(\mathrm{t}, \mathrm{J}=8.8 \mathrm{~Hz}, 1 \mathrm{H}, \mathrm{CH}_{2} \mathrm{O}\right), 4.17(\mathrm{dd}, J=8.0,3.8$ $\mathrm{Hz}, 1 \mathrm{H}, \mathrm{CHOH}), 3.86\left(\mathrm{~d}, J=13.4 \mathrm{~Hz}, 1 \mathrm{H}, \mathrm{CH}_{2} \mathrm{~N}\right), 3.71$ (ddd, $J=9.5,5.9,3.9 \mathrm{~Hz}, 1 \mathrm{H}, \mathrm{CHN}), 3.38(\mathrm{dd}, J=13.4,4.4 \mathrm{~Hz}, 1 \mathrm{H}$, $\left.\mathrm{CH}_{2} \mathrm{~N}\right), 2.09(\mathrm{td}, J=8.4,4.7 \mathrm{~Hz}, 1 \mathrm{H}, \mathrm{CHCHOH}), 1.82(\mathrm{t}, J=$ $\left.4.9 \mathrm{~Hz}, 1 \mathrm{H}, \mathrm{CHCO}_{2}\right), 1.80-1.75\left(\mathrm{~m}, 1 \mathrm{H}, \mathrm{CHCH}_{2} \mathrm{~N}\right) .{ }^{13} \mathrm{C}$ NMR $\left(100 \mathrm{MHz}, \mathrm{D}_{2} \mathrm{O}\right) \delta: 177.7,159.6,64.2,59.8,55.4,38.4$, 26.0, 21.2, 20.0. IR (KBr): 3388, 2991, 2867, 1740, $1732 \mathrm{~cm}^{-1}$. $[\alpha]_{\mathrm{D}}{ }^{25}$ (c 0.02 in $\left.\mathrm{MeOH}\right):-48.87$. Found: C, 51.0; $\mathrm{H}, 4.9 \%$. Calc. for $\mathrm{C}_{9} \mathrm{H}_{11} \mathrm{NO}_{5}$ : C, 50.7; $\mathrm{H}, 5.2 \%$. Mp > $205.4{ }^{\circ} \mathrm{C}$, dec.

(1R,4R, 5S, 6S, 7S)-5-Hydroxy-4-(hydroxymethyl)-3azabicyclo[4.1.0]heptane-7-carboxylic Acid (8a). To a solution of $(5 \mathrm{a} R, 6 \mathrm{~S}, 6 \mathrm{a} S, 7 \mathrm{~S}, 7 \mathrm{a} R)$-7-hydroxy-3-oxohexahydro$1 \mathrm{H}, 3 \mathrm{H}$-cyclopropa $[d]$ oxazolo[3,4-a]pyridine-6-carboxylic acid $(187 \mathrm{mg}, 0.9 \mathrm{mmol}$ ) in $2 \mathrm{~mL}$ of $\mathrm{MeOH}$ is added ethylenediamine $(0.18 \mathrm{~mL}, 2.6 \mathrm{mmol})$ at room temperature and heated at $60{ }^{\circ} \mathrm{C}$ for $1.5 \mathrm{~h}$. The solvent is evaporated in vacuo and methanol is added to evaporate excess amine. A solution of $\mathrm{HCl} 4 \mathrm{~N}$ in dioxane $(5 \mathrm{~mL})$ is added and stirred for $30 \mathrm{~min}$. A yellow wax is obtained $(150 \mathrm{mg}, 91 \%) .{ }^{1} \mathrm{H}$ NMR $(400 \mathrm{MHz}, \mathrm{MeOD}) \delta 4.54\left(\mathrm{t}, J=8.5 \mathrm{~Hz}, 1 \mathrm{H}, \mathrm{CH}_{2} \mathrm{O}\right), 4.14$ $\left(\mathrm{dd}, J=8.9,5.3 \mathrm{~Hz}, 1 \mathrm{H}, \mathrm{CH}_{2} \mathrm{O}\right), 3.86(\mathrm{~d}, J=13.5 \mathrm{~Hz}, 1 \mathrm{H}$, $\mathrm{CH}_{2} \mathrm{~N}$ ), $3.72(\mathrm{~d}, J=8.7 \mathrm{~Hz}, 1 \mathrm{H}, \mathrm{CHOH}), 3.44(\mathrm{dd}, J=13.5$, $\left.4.3 \mathrm{~Hz}, 1 \mathrm{H}, \mathrm{CH}_{2} \mathrm{~N}\right), 3.36(\mathrm{td}, J=8.4,5.2 \mathrm{~Hz}, 1 \mathrm{H}, \mathrm{CHN})$, $1.78-1.70\left(\mathrm{~m}, 1 \mathrm{H}, \mathrm{CHCH}_{2} \mathrm{~N}\right), 1.67(\mathrm{dd}, J=9.2,4.9 \mathrm{~Hz}, 1 \mathrm{H}$, $\mathrm{CHCHOH}), 1.32\left(\mathrm{t}, J=4.9 \mathrm{~Hz}, 1 \mathrm{H}, \mathrm{CHCO}_{2}\right) .{ }^{13} \mathrm{C} \mathrm{NMR}(100$ $\mathrm{MHz}, \mathrm{MeOD}) \delta$ 159.5, 70.1, 69.6, 58.2, 39.6, 28.5, 25.7, 21.3. IR $(\mathrm{NaCl}): 3405,2996,2895,1736 \mathrm{~cm}^{-1} \cdot[\alpha]_{\mathrm{D}}^{25}(c 0.05$ in $\mathrm{MeOH})$ : -5.41 . Found: C, 51.0; $\mathrm{H}, 7.2 \%$. Calc. for $\mathrm{C}_{8} \mathrm{H}_{13} \mathrm{NO}_{4}$ : C, 51.3; $\mathrm{H}, 7.0 \%$.

(1R,4R,5R,6S,7S)-5-Hydroxy-4-(hydroxymethyl)-3-azabicyclo [4.1.0]heptane-7-carboxylic Acid (8b). To a solution of (5aR,6S,6aS,7R,7aR)-7-hydroxy-3-oxohexahydro- $1 \mathrm{H}, 3 \mathrm{H}$ cyclopropa $[d]$ oxazolo $[3,4-a]$ pyridine-6-carboxylic acid $(75 \mathrm{mg}$, $0.4 \mathrm{mmol})$ in $1 \mathrm{~mL}$ of $\mathrm{MeOH}$ is added ethylenediamine $(0.07$ $\mathrm{mL}, 1.1 \mathrm{mmol}$ ) and heated at $60{ }^{\circ} \mathrm{C}$ for $1.5 \mathrm{~h}$. The solvent is evaporated in vacuo and methanol is added to evaporate excess amine. A solution of $\mathrm{HCl} 4 \mathrm{~N}$ in dioxane $(1 \mathrm{~mL})$ is added and stirred for $30 \mathrm{~min}$. A yellow wax is obtained $(60 \mathrm{mg}, 90 \%) .{ }^{1} \mathrm{H}$ NMR (400 MHz, MeOD) $\delta 4.47(\mathrm{dd}, J=8.5,6.0 \mathrm{~Hz}, 1 \mathrm{H}$, $\left.\mathrm{CH}_{2} \mathrm{O}\right), 4.30\left(\mathrm{t}, \mathrm{J}=8.8 \mathrm{~Hz}, 1 \mathrm{H}, \mathrm{CH}_{2} \mathrm{O}\right), 4.16(\mathrm{dd}, J=8.0,3.9$ $\mathrm{Hz}, 1 \mathrm{H}, \mathrm{CHOH}), 3.84\left(\mathrm{~d}, J=13.3 \mathrm{~Hz}, 1 \mathrm{H}, \mathrm{CH}_{2} \mathrm{~N}\right), 3.75-3.62$ (m, 1H, CHN), 3.37 (dd, $\left.J=13.2,4.4 \mathrm{~Hz}, 1 \mathrm{H}, \mathrm{CH}_{2} \mathrm{~N}\right), 2.11-$ $1.93(\mathrm{~m}, 1 \mathrm{H}, \mathrm{CHCHOH}), 1.79-1.64(\mathrm{~m}, 2 \mathrm{H}, 2 \times \mathrm{CH}$ cyclopropane). ${ }^{13} \mathrm{C}$ NMR (100 MHz, MeOD) $\delta 158.80,63.53$, 59.64, 55.65, 38.46, 25.01, 21.50, 19.60. IR ( $\mathrm{NaCl}): 3402$, 2984, 2890, $1733 \mathrm{~cm}^{-1}$. $[\alpha]_{\mathrm{D}}{ }^{25}$ (c 0.02 in $\left.\mathrm{MeOH}\right):-32.0$. Found: C, 51.4; H, 7.2\%. Calc. for $\mathrm{C}_{8} \mathrm{H}_{13} \mathrm{NO}_{4}$ : C, 51.3; H, $7.0 \%$.

(1S, 4R, 5S, 6S, 7S)-4,7-bis(Hydroxymethyl)-3-methyl-3azabicyclo[4.1.0]heptan-5-ol (9). To a solution of $7 \mathbf{a}(120$ $\mathrm{mg}, 0.5 \mathrm{mmol}$ ) in $3 \mathrm{~mL}$ of DCM is added $1.86 \mathrm{~mL}$ of DIBAL$\mathrm{H} 1,2 \mathrm{M}$ in toluene at $0{ }^{\circ} \mathrm{C}$. The reaction is stirred for $4 \mathrm{~h}$ at room temperature. Methanol is added $(10 \mathrm{~mL})$. The salts are filtered and rinsed with methanol $(2 \times 10 \mathrm{~mL})$. The solvent is evaporated in vacuo. The crude is purified in silica gel using $\mathrm{MeCN} / \mathrm{H}_{2} \mathrm{O}$ (9:1) as the eluent. A yellow wax is obtained (49 $\mathrm{mg}, 58 \%$ ). ${ }^{1} \mathrm{H}$ NMR (400 MHz, MeOD) $\delta 3.81$ (dd, $J=11.7$, $\left.3.2 \mathrm{~Hz}, 1 \mathrm{H}, \mathrm{CH}_{2} \mathrm{O}\right), 3.77-3.71\left(\mathrm{~m}, 2 \mathrm{H}, \mathrm{CH}_{2} \mathrm{O}+\mathrm{CHOH}\right)$, 3.45 (dd, $J=11.3,6.7 \mathrm{~Hz}, 1 \mathrm{H} ; \mathrm{HOCH}_{2}$ Ccyclopropane), 3.37 (dd, $J=11.3,6.8 \mathrm{~Hz}, 1 \mathrm{H}, \mathrm{HOCH}_{2} \mathrm{Ccyclopropane}$ ), 3.07 (d, $J=$ $11.7 \mathrm{~Hz}, 1 \mathrm{H}, \mathrm{CH}_{2} \mathrm{~N}$ ), 2.63 (dd, $J=11.6,3.9 \mathrm{~Hz}, 1 \mathrm{H}, \mathrm{CH}_{2} \mathrm{~N}$ ), $2.38\left(\mathrm{~s}, 3 \mathrm{H}, \mathrm{NCH}_{3}\right), 1.75(\mathrm{dt}, J=7.9,2.9 \mathrm{~Hz}, 1 \mathrm{H}, \mathrm{CHN})$,

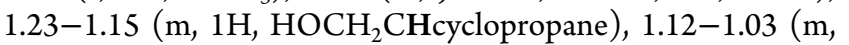
$\left.1 \mathrm{H}, \mathrm{CHCH}_{2} \mathrm{~N}\right), 0.99$ (dd, $\left.J=9.0,4.6 \mathrm{~Hz}, 1 \mathrm{H}, \mathrm{CHCHOH}\right)$. ${ }^{13} \mathrm{C}$ NMR (100 MHz, MeOD) $\delta 70.2,67.1,65.9,60.1,55.6$, 43.0, 23.24, 23.22, 17.3. IR ( NaCl): 3357, 2993, $2892 \mathrm{~cm}^{-1}$. $[\alpha]_{\mathrm{D}}{ }^{25}($ c 0.03 in $\mathrm{MeOH}):-4.65$. Found: C, $57.5, \mathrm{H}, 9.5 \%$. Calc. for $\mathrm{C}_{9} \mathrm{H}_{17} \mathrm{NO}_{3}$ : C, 57.7; $\mathrm{H}, 9.2 \%$.

(5aS, 6S, 6aS, 7R,7aR)-7-Hydroxy-6-(hydroxymethyl)hexahydro- $1 \mathrm{H}, 3 \mathrm{H}$-cyclopropa[d]oxazolo[3,4-a]pyridin-3one (10). To a solution of $7 \mathbf{b}(117 \mathrm{mg}, 0.4 \mathrm{mmol})$ in $3 \mathrm{~mL}$ of DCM at $0{ }^{\circ} \mathrm{C}$ is added $1.80 \mathrm{~mL}$ of $1,2 \mathrm{M}$ DIBAL-H in toluene. The reaction is stirred for $4 \mathrm{~h}$ at room temperature. Methanol is added $(10 \mathrm{~mL})$. The salts are filtered and rinsed with methanol $(2 \times 10 \mathrm{~mL})$. The solvent is evaporated in vacuo. The crude is purified in silica gel using $\mathrm{MeCN}$ as the eluent. A yellow wax is obtained (54 mg, 62\%). ${ }^{1} \mathrm{H}$ NMR (400 MHz, MeOD) $\delta 4.48\left(\mathrm{dd}, J=8.5,5.8 \mathrm{~Hz}, 1 \mathrm{H}, \mathrm{CH}_{2} \mathrm{O}\right), 4.32(\mathrm{t}, J=$ $\left.8.8 \mathrm{~Hz}, 1 \mathrm{H}, \mathrm{CH}_{2} \mathrm{O}\right), 4.16(\mathrm{dd} J=8.1,3.8 \mathrm{~Hz}, 1 \mathrm{H}, \mathrm{CHOH})$, $3.83\left(\mathrm{~d}, J=12.9 \mathrm{~Hz}, 1 \mathrm{H}, \mathrm{CH}_{2} \mathrm{~N}\right), 3.69$ (ddd, $J=9.4,5.8,3.8$ $\mathrm{Hz}, 1 \mathrm{H}, \mathrm{CHN}), 3.54(\mathrm{dd}, J=11.2,6.4 \mathrm{~Hz}, 1 \mathrm{H}$,

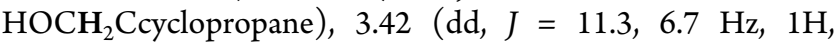
$\mathrm{HOCH}_{2}$ Ccyclopropane), 3.36 (dd, 12.9, $4.7 \mathrm{~Hz}, 1 \mathrm{H}, \mathrm{CH}_{2} \mathrm{~N}$ ), $1.42(\mathrm{td}, J=8.4,4.9 \mathrm{~Hz}, 1 \mathrm{H}, \mathrm{CHCHOH}), 1.30-1.20(\mathrm{~m}, 1 \mathrm{H}$, $\mathrm{HOCH}_{2} \mathrm{CH}$ cyclopropane), 1.19-1.09 (m, 1H, $\left.\mathrm{CHCH}_{2} \mathrm{~N}\right)$. ${ }^{13} \mathrm{C}$ NMR (100 MHz, MeOD) $\delta 160.4,65.6,65.0,61.4,57.2$, 40.2, 21.9, 21.0, 16.5. IR ( NaCl): 3384, 2991, 2888, 1705 $\mathrm{cm}^{-1}$. $[\alpha]_{\mathrm{D}}{ }^{25}($ c 0.01 in $\mathrm{MeOH}):-35.3$. Found: C, 54.5; H, $6.5 \%$. Calc. for $\mathrm{C}_{9} \mathrm{H}_{13} \mathrm{NO}_{4}$ : C, 54.3; $\mathrm{H}, 6.6 \%$.

General Procedure for Enzymatic Reactions. Glycosidase activities were assessed in $80 \mu \mathrm{L}$ reaction volumes in Eppendorf vials. Buffer composition and enzyme concentration were adjusted depending on the enzyme assayed: $20 \mathrm{mM}$ $\mathrm{Na}_{2} \mathrm{HPO}_{4}$ at $\mathrm{pH} 7.3$ for $\beta$-glucosidase $(3 \mu \mathrm{g} / \mathrm{mL})$ and $\beta$ galactosidase $(1 \mu \mathrm{g} / \mathrm{mL}) ; 20 \mathrm{mM} \mathrm{Na} \mathrm{HPO}_{4}$ at $\mathrm{pH} 6.8$ for $\alpha$ glucosidase $(1 \mu \mathrm{g} / \mathrm{mL})$ and $\alpha$-galactosidase $(20 \mu \mathrm{M}) ; 20 \mathrm{mM}$ $\mathrm{NaH}_{2} \mathrm{PO}_{4}$ at $\mathrm{pH} 5.5$ for $\alpha$ - and $\beta$-mannosidase ( 7 and $2 \mu \mathrm{M}$ respectively); $0.1 \mathrm{M} \mathrm{NaOAc}$ at $\mathrm{pH} 4.0$ with $1 \mathrm{mg} / \mathrm{mL}$ of bovine serum albumin (BSA) for $\alpha$-L-fucosidase $(2 \mu \mathrm{M})$; and $50 \mathrm{mM} \mathrm{NaOAc}$ at $\mathrm{pH} 5.0$ for neuraminidase $(6 \mu \mathrm{M})$. The inhibitors were tested at 1,5 , and $25 \mathrm{mM}$ final concentrations in the assays. Each enzyme mixture and inhibitor were homogenized and preincubated for $10 \mathrm{~min}$ at 37 or $40{ }^{\circ} \mathrm{C}$ ( $\alpha$-L-fucosidase). Each reaction was initiated and brought to a final volume of $80 \mu \mathrm{L}$, by addition of an aliquot of the corresponding $p$-nitrophenyl glycoside substrate to obtain the following final concentrations in the reaction mixtures: $p$ nitrophenyl $\alpha$ - and $\beta$-D-glucopyranoside $(1 \mathrm{mM}), p$-nitrophenyl $\alpha$ - and $\beta$-D-galactopyranoside $(0.5 \mathrm{mM}), p$-nitrophenyl $\alpha$ - and $\beta$-D-mannopyranoside $(1 \mathrm{mM}), p$-nitrophenyl $\alpha$-Lfucopyranoside $(1 \mathrm{mM})$, or $p$-nitrophenyl neuraminic acid (1 $\mathrm{mM})$. After $10 \mathrm{~min}$ of incubation time at the same temperature, each reaction was quenched with $400 \mu \mathrm{L}$ of 1.0 $\mathrm{M} \mathrm{Na} \mathrm{CO}_{3}$, and the absorbance at $405 \mathrm{~nm}$ was measured. Assays were repeated twice and data were averaged. 
The residual activity of each enzyme was calculated by the ratio of the absorbance measured after $10 \mathrm{~min}$ of reaction in the presence and absence of synthesized compounds. The equation used to calculate $K_{\mathrm{i}}$ was derived from MichaelisMenten, where $V_{\mathrm{i}}$ is the absorbance measured in the absence of the synthesized compounds; $V$ is the absorbance when the compounds were added to the enzymatic reaction; $K_{\mathrm{m}}$ indicates the Michaelis-Menten constant for each enzyme; and $[\mathrm{I}]$ is the concentration of the synthesized compounds (5 $\mathrm{mM}$ ) and $[S]$ is the concentration of the substrate (eq 1 ).

Calculated $K_{\mathrm{i}}$ for compounds $8 \mathrm{a}$ and 9

$$
K_{\mathrm{i}}=\frac{K_{\mathrm{m}}[I]}{\left(K_{\mathrm{m}}+[S]\right)\left(V / V_{\mathrm{i}}-1\right)}
$$

\section{ASSOCIATED CONTENT}

\section{SI Supporting Information}

The Supporting Information is available free of charge at https://pubs.acs.org/doi/10.1021/acsomega.0c04589.

${ }^{1} \mathrm{H}$ NMR, ${ }^{13} \mathrm{C}$ NMR, and IR spectra of synthesized compounds (PDF)

\section{AUTHOR INFORMATION}

\section{Corresponding Author}

Javier Pérez-Castells - Department of Chemistry and Biochemistry, Facultad de Farmacia, Universidad San PabloCEU, CEU Universities, 28668 Boadilla del Monte, Madrid, Spain; orcid.org/0000-0002-7256-0723;

Email: jpercas@ceu.es

\section{Authors}

Alejandro Puet - Department of Chemistry and Biochemistry, Facultad de Farmacia, Universidad San Pablo-CEU, CEU Universities, 28668 Boadilla del Monte, Madrid, Spain

Gema Domínguez - Department of Chemistry and Biochemistry, Facultad de Farmacia, Universidad San PabloCEU, CEU Universities, 28668 Boadilla del Monte, Madrid, Spain

F. Javier Cañada - Dep. Biología FisicoQuímica, CIB Margarita Salas, 28040 Madrid, Spain; CIBER de Enfermedades Respiratorias (CIBERES), 28029 Madrid, Spain; (1) orcid.org/0000-0003-4462-1469

Complete contact information is available at: https://pubs.acs.org/10.1021/acsomega.0c04589

\section{Notes}

The authors declare no competing financial interest.

\section{ACKNOWLEDGMENTS}

Funding of this project by the Spanish MINECO, Grant no. RTI2018-095588-B-I00 and RTI2018-094751-B-C22 (Cofunded by European Regional Development Fund/European Social Fund, "Investing in your future"), FUSP-CEU (PC17/ 17) and CIBERES, an initiative from the Spanish Institute of Health Carlos III are acknowledged.

\section{REFERENCES}

(1) (a) Compain, P.; Martin, O. R. Iminosugars: from Synthesis to Therapeutical Applications; John Wiley \& Sons: Chichester, U.K., 2008. (b) Stütz, A. E. Iminosugars as Glycosidase Inhibitors: Nojirimycin and Beyond. Stütz, A. E., Ed.; Wiley-VCH Verlag
GmbH \& Co. KGaA: Weinheim, FRG, 1998. (c) Butters, T. D.; Dwek, R. A.; Platt, F. M. Inhibition of Glycosphingolipid Biosynthesis: Application to Lysosomal Storage Disorders. Chem. Rev. 2000, 100, 4683-4696. (d) Malik, M.; Jarosz, S. Recent advances in the synthesis of iminosugars. An insight into the cascade addition of Grignard reagents to halo-nitriles/cyclization. Carbohydr. Chem. 2017, 42, 313-343. (e) Rempel, B. P.; Withers, S. G. Covalent inhibitors of glycosidases and their applications in biochemistry and biology. Glycobiology 2008, 18, 570-586. (f) Asano, N. Glycosidase inhibitors: update and perspectives on practical use. Glycobiology 2003, 13, 93R104R.

(2) For biological activity of iminosugars, see: (a) Miller, J. L.; Tyrrell, B. E.; Zitzmann, N. Mechanisms of antiviral activity of iminosugars against dengue virus. Adv. Exp. Med. Biol. 2018, 1062, 277-301. (b) Tyrrell, B. E.; Sayce, A. C.; Warfield, K. L.; Miller, J. L.; Zitzmann, N. Iminosugars: Promising therapeutics for influenza infection. Crit. Rev. Microbiol. 2017, 43, 521-545. (c) Horne, G. Iminosugars: Therapeutic Applications and Synthetic Considerations. Top. Med. Chem. 2014, 12, 23-51. (d) Horne, G.; Wilson, F. X.; Tinsley, J.; Williams, D. H.; Storer, R. Iminosugars past present and future: medicines for tomorrow. Drug Discovery Today 2011, 16, 107118. (e) Nash, R. J.; Kato, A.; Yuand, C.-Y.; Fleet, G. W. Iminosugars as therapeutics agents: recent advances and promising trends. Future Med. Chem. 2011, 3, 1513-1521. (f) Gerber-Lemaire, S.; JuilleratJeanneret, L. Glycosylation pathways as drug target for cancer: glycosidase inhibitors. Mini-Rev. Med. Chem. 2006, 6, 1043-1052.

(3) (a) Cardona, F.; Goti, A.; Brandi, A. (+)-Lentiginosine, a potent and selective inhibitor of amyloglucosidase: synthetic efforts and disputes on its absolute configuration. Eur. J. Org. Chem. 2007, 2007, 1551-1565. (b) Cordero, F. M.; Giomi, D.; Brandi, A. Recent Syntheses and biological activity of lentiginosine and its analogues. Curr. Top. Med. Chem. 2014, 14, 1294-1307. (c) Wrodnigg, T. M.; Steiner, A. J.; Ueberbacher, B. J. Natural and synthetic iminosugars as carbohydrates processing enzymes inhibitors for cancer therapy. AntiCancer Agents Med. Chem. 2008, 8, 77-85.

(4) (a) Joubert, P. H.; Veuter, C. P.; Joubert, H. F.; Hillebrand, I. The effect of a 1-Deoxynojirimycin derivative on post-prandial blood glucose and insulin level in healthy black and white volunteers. Eur. J. Clin. Pharmacol. 1985, 28, 705-708. (b) Winchester, B. G. Iminosugars: from botanical curiosities to licensed drugs. Tetrahedron: Asymmetry 2009, 20, 645-651.

(5) (a) Benjamin, E. R.; Flanagan, J. J.; Schilling, A.; Chang, H. H.; Agarwal, L.; Katz, E.; Wu, X.; Pine, C.; Wustman, B.; Desnick, R. J.; Lockhart, D. J.; Valenzano, K. J. The pharmacological chaperone 1deoxygalactonojirimycin increases $\alpha$-galactosidase A levels in Fabry patient cell lines. J. Inherited Metab. Dis. 2009, 32, 424-440. (b) Fan, J.-Q.; Ishii, S.; Asano, N.; Suzuki, Y. Accelerated transport and maduration of lysosomal $\alpha$-galactosidase A in Fabry lymphoblasts by an enzyme inhibitor. Nat. Med. 1999, 5, 112-115.

(6) (a) Yoshikuni, Y.; Ezure, Y.; Seto, T.; Mori, K.; Watanabe, M.; Enomoto, H. Synthesis and $\alpha$-glucosidase-inhibition of a new $\alpha$ glucosidase inhibitor, 4-O- $\alpha$-D-glucopyranosyl moranoline and its $\mathrm{N}$ substituted derivatives. Chem. Pharm. Bull. 1989, 37, 106-109. (b) Markad, S. D.; Karanjule, N. S.; Sharma, T.; Sabharwal, S. G.; Dhavele, D. D. Synthesis and evaluation of glycosidase inhibitory activity of N-butyl-1-deoxy-D-gluco-homonojirimycin and N-butyl-1deoxy-L-ido-homonojirimycin. Bioorg. Med. Chem. 2006, 14, 55355539.

(7) (a) Lillelund, V. H.; Jensen, H. H.; Liang, X.; Bols, M. Recent developments of transition-state analogue glycosidase inhibitors of non-natural product origin. Chem. Rev. 2002, 102, 515-553. (b) Wolfenden, R.; Snider, M. J. The depth of chemical time and the power of enzymes as catalysts. Acc. Chem. Res. 2001, 34, 938-945.

(8) (a) Davies, G. J.; Planas, A.; Rovira, C. Conformational analyses of the reaction coordinate of glycosidases. Acc. Chem. Res. 2012, 45, 308-316. (b) Speciale, G.; Thompson, A. J.; Davies, G. J.; Williams, S. J. Dissecting conformational contributions to glycosidase catalysis and inhibition. Curr. Opin. Struct. Biol. 2014, 28, 1-13. 
(9) Thompson, A. J.; Speciale, G.; Iglesias-Fernandez, J.; Hakki, Z.; Belz, T.; Cartmell, A.; Spears, R. J.; Chandler, E.; Temple, M. J.; Stepper, J.; Harry, J. G.; Rovira, C.; Spencer, J. W.; Gideon, J. D. Evidence for a boat conformation at the transition state of GH76 $\alpha$ 1,6-mannanases key enzymes in bacterial and fungal mannoprotein metabolism. Angew. Chem., Int. Ed. 2015, 54, 5378-5382.

(10) Beenakker, T. J. M.; Wander, D. P. A.; Offen, W. A.; Artola, M.; Raich, M.; Ferraz, M. J.; Li, K.-Y.; Houben, J. H. P. M.; van Rijssel, E. R.; Hansen, T.; van der Marel, G. A.; Codée, J. D. C.; Aerts, J. M. F. G.; Rovira, C.; Davies, G. J.; Overkleeft, H. S. Carba-cyclophellitols are neutral retaining-glucosidase inhibitors. J. Am. Chem. Soc. 2017, 139, 6534-6537.

(11) (a) Wardrop, D. J.; Waidyarachchi, S. L. Synthesis and biological activity of naturally occurring $\alpha$-glucosidase inhibitor. Nat. Prod. Rep. 2010, 27, 1431-1468. (b) Compain, P. Glycomimetics: Design, synthesis and therapeutic applications. Molecules 2018, 23, 1658-1660. (c) Stocker, B. L.; Dangerfield, E. M.; Win-Mason, A. L.; Haslett, G. W.; Timmer, M. S. M. Recent developments in the synthesis of pyrrolidine-containing iminosugars. Eur. J. Org. Chem. 2010, 2010, 1615-1637.

(12) (a) Clemente, F.; Matassini, C.; Cardona, F. The reductive amination routes to the synthesis of piperidine iminosugars. Eur. J. Org. Chem. 2020, No. 4447. (b) Wang, B.; Bogh, S. A.; Navarro Poulsen, J. C.; Laursen, B. W.; Bols, M. Synthesis of isofagomine derivatives as new fluorescence $\mathrm{pH}$ indicators/glycosidase inhibitors. Eur. J. Org. Chem. 2020, 2020, 3989-3996. (c) Iftikhar, M.; Wang, L.; Fang, Z. Synthesis of 1-deoxynojirimycin: exploration of optimised conditions for reductive amidation and separation of epimers. J. Chem. Res. 2017, 41, 460-464.

(13) (a) Wood, A.; Prichard, K. L.; Clarke, Z.; Houston, T. A.; Fleet, G. W. J.; Simone, M. I. Synthetic pathways to 3,4,5-trihydroxipiperidines from the chiral pool. Eur. J. Org. Chem. 2018, 2018, 68126829. (b) Chavan, S. R.; Gavale, K. S.; Khan, A.; Joshi, R.; Kumbhar, N.; Chakravarty, D.; Dhavale, D. D. Iminosugars spiro-linked with morpholine-fused 1,2,3-triazole: synthesis, conformational analysis, glycosidase inhibitory activity, antifugal assay and docking studies. ACS Omega 2017, 2, 7203-7218. (c) Moynihan, L.; Chadda, R.; McArdle, P.; Murphy, P. V. Allylic azide rearrangement in tandem with Huisgen cycloaddition for stereoselective annulations: synthesis of C-glycosiliminosugars. Org. Lett. 2015, 17, 6226-6229.

(14) (a) Prichard, K. L.; O’Brien, N.; Ghorbani, M.; Wood, A.; Barnes, E.; Kato, A.; Houston, T. A.; Simone, M. I. Synthetic routes to 3,4,5-trihydroxipiperidines via stereoselective and biocatalysed protocols, and strategies to $\mathrm{N}$ - and O-derivatisation. Eur. J. Org. Chem. 2018, 2018, 6830-6842. (b) De Angelis, M.; Primitivo, L.; Lucarini, C.; Agostinelli, S.; Sappino, C.; Ricelli, A.; Righi, G. Stereocontrolled total synthesis of iminosugars 1,4-dideoxy-1,4-imino-D-iditol. Carbohydr. Res. 2020, 492, No. 108028.

(15) (a) Ribes, C.; Falomir, E.; Murga, J.; Carda, M.; Marco, J. A. Convergent, stereoselective syntheses of the glycosidase inhibitors broussonetines D and M. Org. Biomol. Chem. 2009, 7, 1355-1360. (b) Jeon, J.; Lee, J. H.; Kim, J.-W.; Kim, Y. G. Syn-Selective dihydroxylation of $\gamma$-amino- $\alpha, \beta$-unsaturated $(Z)$-esters from $\mathrm{D}$-serine: setereoselctive synthesis of $\mathrm{D}$-iminolyxitol. Tetrahedron: Asymmetry 2007, 18, 2448-2453. (c) Hulme, A. N.; Montgomery, C. H. Stereoselective synthesis of the $\alpha$-glucosidase inhibitor nectrisine. Tetrahedron Lett. 2003, 44, 7649-7653. (d) Boto, A.; RomeroEstudillo, I. One-Pot stereoselective synthesis of 1,2-amino alcohol derivatives. Org. Lett. 2011, 13, 3426-3429. (e) Cong, X.; Liu, K.-G.; Liao, Q. J.; Yao, Z.-J. Preparation of enantiomerically pure 2-(1'aminomethyl) furan derivatives and synthesis of an unnatural polyhydroxylated piperidine. Tetrahedron Lett. 2005, 46, 85678571. (f) Grandel, R.; Kazmaier, U.; Rominger, F. Short syntheses of polyhydroxylated $\alpha$-alkylated amino acids. J. Org. Chem. 1998, 63, 4524-4528. (g) Rengasamy, R.; Curtis-Long, M. J.; Ryu, H. W.; Oh, K. Y.; Park, K. H. Stereoselective synthesis of L-deoxyaltronojirimycin from L-serine. Bull. Korean Chem. Soc. 2009, 7, 1531-1534.

(16) The only previously described cyclopropane containing iminosugar: (a) Désiré, J.; Shipman, M. Iminoglycals in synthesis: preparation of novel deoxymannojirimycin analogues. Synlett 2001 2001, 1332. See also: (b) López-Rodríguez, A.; Domínguez, G.; Pérez-Castells, J. Synthesis of novel iminosugars derivatives based on a 2-azabicyclo [4.1.0] heptanes skeleton. Synthesis 2017, 49, 46064612. Spirocycle containing iminosugars: (c) Hazelard, D.; Hensienne, R.; Behr, J. B.; Compain, P. Spiro iminosugars: structural diversity and synthetic strategies. Top. Heterocycl. Chem. 2019, 57, 261-290.

(17) Moriarty, R. M. $(1 R, 4 R)$ 7-Oxo-2-azabiciclo [2.2.2] oct-5-ene and their derivatives as intermediates of pharmaceutically important compounds containing the isoquinuclidene moiety and their preparation. US Patent WO2013112622A1, 2013.

(18) Moisan, L.; Thuéry, P.; Nicolas, M.; Doris, E.; Rousseau, B. Formal synthesis of (+)-Catharanthine. Angew. Chem., Int. Ed. 2006, $45,5334-5336$.

(19) For a review on RCM reaction for the synthesis of iminosugars, see: Dragutan, I.; Dragutan, V.; Demonceau, A. Targeted drugs by olefin metathesis: piperidine-based iminosugars. RSC $A d v$. 2012, 2, $719-736$.

(20) (a) Appel, R.; Hartman, N.; Mayr, H. Scope and limitations of cyclopropanations with sulphur ylides. J. Am. Chem. Soc. 2010, 132, 17894-17900. (b) Appel, R.; Mayr, H. Nucleophilic reactivities of sulphur ylides and related carbanions: comparison with structurally related organophosphorous compounds. Chem. - Eur. J. 2010, 16, 8610-8614. For the synthesis of ylide see: (c) Henry, S. S.; Brady, M. D.; laird, D. L. T.; Ruble, J. C.; Varie, D. L.; Monn, J. A. Improved synthesis of $\mathrm{C} 4 \alpha$ - and C4 $\beta$-Methyl analogues of 2 -Aminobicyclo [3.1.0] hexane -2,6-dicarboxylate. Org. Lett. 2012, 14, 2662-2665.

(21) Romo, D.; Meyers, A. I. An asymmetric route to enantiomerically pure 1,2,3-trisubstituted cyclopropanes. J. Org. Chem. 1992, 57, $6265-6270$.

(22) Zhang, R.; Mamai, A.; Madalengoitia, J. S. Cyclopropanation Reactions of Pyroglutamic Acid-Derived Synthons with Akylidene Transfer Reagents. J. Org. Chem. 1999, 64, 547-555.

(23) (a) Riches, S. L.; Saha, C.; Filgueira, N. F.; Grange, E.; McGarrigle, E. M.; Aggarwal, V. K. On the mechanism of ylidemediated cyclopropanations: evidence for a proton-transfer step and its effects on stereoselectivity. J. Am. Chem. Soc. 2010, 132, 76267630. (b) Aggarwal, V. K.; Grange, E. Asymmetric sulfonium ylide mediated cyclopropanation: stereocontrolled synthesis of (+)-LY354740. Chem. - Eur. J. 2006, 12, 568-575.

(24) Modelling was done using Chimera 1.13.1, charges were computed using ANTECHAMBER: Wang, J.; Wang, W.; Kollman, P. A.; Case, D. A. Automatic atom type and bond perception in molecular mechanical calculations. J. Mol. Graphics Modell. 2006, 25, $247-260$.

(25) Gonda, T.; Balázs, A.; Tóth, G.; Fülöp, F.; Szakonyi, Z. Stereoselective synthesis and transformations of pinane-based 1,3diaminoalcohols. Tetrahedron 2017, 73, 2638-2648.

(26) (a) Russell, R. J.; Haire, L. F.; Stevens, D. J.; Collins, P. J.; Lin, Y. P.; Blackburn, G. M.; Hay, A. J.; Gambling, S. J.; Skehel, J. J. The structure of $\mathrm{H} 5 \mathrm{~N} 1$ avian influenza neuraminidase suggest new opportunities for drug design. Nature 2006, 443, 45-49. (b) Lew, W.; Chen, X.; Kim, C. U. Discovery and development of GS 4104 (oseltamivir): an orally active influenza neuraminidase inhibitor. Curr. Med. Chem. 2000, 7, 663-672.

(27) PDB file of N8 Neuraminidase from Influenza virus in complex with oseltamivir (2HT8) was obtained from Protein data Bank. Ligands were first minimized as ref 22. Docking was calculated using Lamarckian Genetic Algorithm parameters.

(28) Zamoner, L. O. B.; Aragao-Leoneti, V.; Carvalho, I. Iminosugars: effects of stereochemistry, ring size and $N$-substituents on glucosidase activities. Pharmaceuticals 2019, 12, No. 108.

(29) Haarr, M. B.; López, O.; Pejov, L.; Fernández-Bolaños, J. G.; Lindbäck, E.; Sydnes, M. O. 1,4-dideoxy-1,4-imino-D-arabinitol (DAB) analogues possessing a hydrazide imide moiety as potent and selective $\alpha$-mannosidase inhibitors. ACS Omega 2020, 5, 1850718514. 
(30) Brissonnet, Y.; Ladevèze, S.; Tezé, D.; Fabre, E.; Deniaud, D.; Deligault, F.; Tellier, C.; Sesták, S.; Remaud-Simeon, M.; PotockiVeronese, G.; Gouin, S. G. Polymeric iminosugars improve the activity of carbohydrate-processing enzymes. Bioconjugate Chem. 2015, 26, 766-772.

(31) Darby, J. F.; Landström, J.; Roth, C.; He, Y.; Davies, G. J.; Hubbard, R. E. Discovery of selective small-molecule activators of a bacterial glycoside hydrolase. Angew. Chem., Int. Ed. 2014, 53, 1341913423. 